\title{
Parent-Child Relationship Cases Before the ECtHR
}

\author{
https://doi.org/10.21272/sec.4(1).36-64.2020
}

Dagmara Rajska, ORCID: https://orcid.org/0000-0001-5256-1246

$\mathrm{PhD}$, Postdoctoral Researcher, Molengraaff Institute for Private Law \& UCERF (Utrecht Centre for European Research into Family Law), Faculty of Law, Economics and Governance, Utrecht University (2018-2019), The Netherlands

\begin{abstract}
This paper summarizes the arguments and counterarguments within the scientific discussion on the issue of choosing between Article 6 (Right to a fair trial) or/and Article 8 (Right to family life) of the European Convention on Human Rights (hereafter 'ECHR') when being applied by the European Court of Human Rights (hereafter 'ECtHR') in parent-child relationship cases. The main purpose of this research is to understand these provisions and their interplay. There is no particular systematization of literary sources and approaches for solving this problem, because it is new. The analysis of applications lodged before the ECtHR indicates that the applicants usually raise both provisions for the reason of procedural safety. What is the response of the ECtHR? The investigation in this paper concerning the topic "what is protected by which provision, and is there any pattern in the application of Articles 6 and 8 in cases involving both provisions?' is carried out in the following logical sequence: Relevant legal framework (Section 2); Research interest and question (Section 3); Research methodology (Section 4); Parental authority, custody, and access/contact, regarding cases respectively involving Articles 6 and 8 ECHR (Section 5). The methodological tool of the research method was the ECtHR Hudoc database. The object of the research is the ECtHR, because, namely, this institution interprets Article 6 and Article 8 of the ECHR. The paper presents the results of an empirical analysis of 212 judgments delivered by the ECtHR during the last twenty years. These showed that, with regard to the interplay between Articles 6 and 8 ECHR, there are some trends in its case-law which give guidance to the applicants, the judges and other practitioners concerned, as well as to scholars. The results of the research can be useful in efficiently analysing, applying, defending and adjudicating these rights.
\end{abstract}

Keywords: right to a fair trial, right to family life, parental authority, parental care, access / contact, European Convention on Human Rights.

JEL Classification: K15, K36, K38, K41.

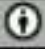

This work is licensed under a Creative Commons Attribution 4.0 International License.

Cite as: Dagmara Rajska (2020). Parent-Child Relationship Cases Before the ECtHR. SocioEconomic Challenges, 4(1), 36-64. https://doi.org/10.21272/sec.4(1). 36-64.2020.

(C) The Author, 2020. This article is published with open access at Sumy State University.

\section{Introduction}

This article is a comparative study of the case-law of the European Court of Human Rights (hereafter: 'the ECtHR' or 'the Court'), which deals with the right to a fair trial in parent-child relationship cases. It is based on research involving 1504 and analysing thoroughly 212 relevant judgments of the ECtHR delivered in the last twenty years (1998-2018). ${ }^{1}$ The methodology of the research is described in detail in Section 4 of this article and the comparative table of concerned judgments follows in the annex.

The European Convention on Human Rights (hereafter: 'the ECHR' or 'the Convention') protects several human rights which are related to the family. Articles 6 and 8 are cornerstone provisions and they interact with each other. Article 6 was created for the procedural rights of litigants, in particular for a fair trial before

\footnotetext{
${ }^{1}$ The extensive survey of Articles 6 and 8 parent-child relationship cases was conducted through the Court's HUDOC database system. The HUDOC database is available
} https://hudoc.echr.coe.int/eng\#\{"documentcollectionid2":["GRANDCHAMBER","CHAMBER"]\} (visited 22 May 2019). 
an independent and impartial authority, as established by law and within a reasonable time. At the same time, Article 8 ECHR, protecting private life and family life (parental authority and custody, access to a child, etc.), has been developed into a rich set of protected interests including rights which traditionally belonged to the domain of Article 6 ECHR. In this research study, the interaction between the two provisions is the central issue: what is protected by which provision? This is the idea which developed into the research question described in Section 3 of this article.

This paper is divided into six sections: 1. Introduction 2. Relevant legal framework 3. Research interest and question 4. Research methodology 5. Analysis and interpretation of research results (Parental authority, Parental custody, Access/Contact with a child) 6. Conclusion.

\section{Relevant legal framework}

We first need to look separately at Articles 6 and 8 one by one in order to understand their application and the intricate interplay between them in the case-law of the ECtHR.

Article 6 provides the right to a fair trial and is an omnibus provision which has been described as enshrining 'the principle of the rule of law, upon which a democratic society is built, and the paramount role of the judiciary in the administration of justice, reflecting the common heritage of the Contracting States' (Vitkauskas, Dikov 2017; Cremona 1990). Article 6 further emphasizes 'a position of pre-eminence (of Article 6 ) in the Convention, both because of the importance of the right involved and the great volume of applications and jurisprudence that it has attracted' (Harris, O’Boyle, Bates, Buckley, et al. 2018; Mole, Harby 2006).

There are a number of 'specific ingredients' of a fair trial which have emerged from the case-law: 'procedural equity, an adversarial process and disclosure of evidence, a reasoned decision, appearance in person, and effective participation' (Rainey, Wicks, Ovey 2014). The right to a fair trial also consists of a right to an involvement in the judiciary decision-making process, understood as 'the right to effectively participate in a trial, have a right to express a view before the courts, to hear and to question witnesses, to submit evidence and to react to evidence submitted by other parties' (Hofmański, Wróbel 2010). However, in accordance with subsidiarity and fourth-instance doctrine (Çali 2016), it gives no power to the ECtHR to substitute its own assessment of evidence, which is a competence reserved to national courts. Among the specific guarantees enshrined in Article 6 para 1 are also: the right to a fair trial before an independent and impartial tribunal (Rädler 1998; Quillere-Majzoub 1999) established by law and the right to public judgments rendered in a reasonable time.

The ECtHR fills some of these lacunae with other provisions of the Convention and Protocols. The ECtHR also reads 'procedural guarantees into some of the substantive rights under the Convention, among them Article 8' (Robin, White, Ovey 2010).

Article 8 protects the right to private and family life, and this study focuses on the right to family life. Family ties exist for parents and children, including illegitimate and adopted children, from the moment of a child's birth and they cease to exist only under exceptional circumstances (ECtHR, Gül, para 32). For relationships between extended family members, the ECtHR accepts that they fall within the concept of family life provided there are 'additional factors of dependence, other than normal emotional ties' (ECtHR, Senchishak, para 55).

The ECtHR examines the facts of the concerned case to decide if there is family life. However, the relationship between the parents and the children has such a typical form, that there is a presumption of the existence of 'family life' (Garlicki 2010).

This presumption is strongest between the children and their mother (ECtHR, Kearns, para 72). It also exists between the children and their father regardless of whether if the parents are married or not (ECtHR, Johnston, paras 56-57), if the father has recognized the children and if he lives with them (ECtHR, Keegan, para 44). The presumption is rebutted only if there has never been a real relationship between the father and the children (ECtHR, L., paras 37-40) or if the relationship between them no longer exists.

The article focuses on the core areas of 'family life', in particular parental authority, parental custody, and contact with/access to a child. The understanding of these terms for the needs of the research and this study is explained in Section 5.1. 
The in-depth research of the case-law will determine if there are, firstly, cases in which Article 6 (the right to a fair trial) should be raised rather than Article 8 (the right to family life) and, secondly, cases in which Article 8 should be raised rather than Article 6 by the applicants before the ECtHR in order to gain a more effective protection of their rights.

\section{Research interest and question}

The article sets out to answer the following research question:

'In cases involving Articles 6 and 8 ECHR, are there clear guidelines for the application of these provisions by the European Court of Human Rights?'

The article focuses on the substantive ambit of the right to family life (Article 8 ECHR), more particularly: parental authority, parental custody and access to a child. It further outlines the procedural rights (Articles 6 and 8 ECHR) related to each of the above-mentioned substantive rights. The understanding of substantive and procedural rights is described in detail in the next sections of this article.

The study examines how the ECtHR deals with the cases involving Article 6 or/and Article 8 of the Convention. It seeks the guidance and the patterns in the application of both Articles by the Court. It also looks for the situations in which the Court would ex officio place the complaints under the provision that is the most appropriate. In affirmative, it notes if the Government objected to the fact that the Court examined the allegation under the provision which has not been explicitly raised by the applicant in his/her application. The author also wonders whether or not the issue of categorisation of the complaint under Articles 6 and 8 has an impact on the adequate dealing with the merits of the case by the ECtHR.

The societal impact of the research findings is important especially for the applicants and their legal representatives before the Court. It aims to give them the information how to submit their application in an effective manner. In particular, an allegation addressed under a wrong provision may even result in the inadmissibility of their case (ECtHR 2019 Annual Report).

Many times, including in the context of Articles 6 and 8 ECHR, the ECtHR calls itself: 'the master of the characterization to be given in law to the facts of the case' (ECtHR, Soares de Melo para 65; Mitovi para 49; Macready para 41; Havelka para 35). In this situation, it is not bound by the characterization given by the applicant or the Government. Thus, the Court will consider under which Article(s) the complaints should be examined' (ECtHR 2019 Guide on Article 8).

Firstly, the Court explains that a difference between the purpose pursued by the respective safeguards afforded by Articles 6 and 8 may, in light of the particular circumstances, justify the examination of the same set of facts under both provisions.

For example, the right of access and custody of children is a civil right protected under Article 6, but also an element of family life protected under Article 8. In one case, under Articles 6 and 8, the ECtHR examined the refusal of access to a child based on a parental arrangement concerning the rights over the children, which could not be reviewed by a court (ECtHR, $R$., paras 60,63-75, 76-88). Similarly, under Articles 6 and 8, the ECtHR examined the case of a father who was excluded from adoption proceedings (ECtHR, Keegan; Hofmański, Wróbel 2010).

In general, Article 6 affords a procedural safeguard, namely, 'the right to a court' in the determination of one's 'civil rights and obligations', whereas the procedural requirement of Article 8 does not cover only administrative procedures as well as judicial proceedings, but it is also ancillary to the wider purpose of ensuring proper respect for, inter alia, family life (Tapia Gasca and D. paras 111-113; Bianchi para 112; ECtHR 2019, Guide on Article 8).

Secondly, in cases where family life is at stake and the applicants invoke Articles 6 and 8 , the Court can decide to examine the facts solely under Article 8 . The reasons for this will be analysed later in the article, but some random examples show the existence of this interplay between Articles 6 and 8. For example, in one case, the ECtHR examined the non-enforcement of a decision on the right to have contact with a child under Article 8 (Mitovi para 49). Likewise, in another case, the Court examined the authorities' inactivity and the excessive length of enforcement proceedings related to the custody of a child under Article 8 (ECtHR, Santos Nunes paras 54-56). Moreover, in several cases where a close link was found between the complaints raised under 
Articles 6 and 8, the Court has considered the complaint under Article 6 as being part of the complaint under Article 8 (ECtHR, G.B. para 113).

Finally, in some family cases, in which both provisions were invoked, the Court has concluded that there was a violation of procedural guarantees under Article 6, without finding a breach of Article 8 (ECtHR, Aresti Charalambous; Rajska 2015).

At the first glance, there is no clear pattern of application of Article 6 and Article 8 ECHR, but the good observer finds some guidelines for the application of these provisions in the arguments given by the Court in the relevant cases. The existence of guidelines is also important because the lack of any guidelines would mean that the ECtHR is inconsistent in its approach in cases involving Articles 6 and 8.

The ECtHR is not itself a party to the European Convention on Human Rights. ${ }^{2}$ However, 'the risk of inconsistency' of its case-law is mentioned in the Convention itself: 'Article 30 (of the ECHR) provides that, if such a risk arises out of a pending case, the Chamber may relinquish jurisdiction in favour of the Grand Chamber, unless one of the parties objects. One of the intended functions of the Grand Chamber is thus to contain the risk of inconsistency'(Costa 2008).

At present, the close observer notices that, in cases involving the possible application of Articles 6 and 8, for reasons of procedural safety, the litigants usually raise both provisions before the ECtHR. This article aims to provide guidance for the litigants and the legal practitioners so as to make them raise the most relevant provision before the ECtHR.

The joint applicability of Article 6 or/and Article 8 in all family law matters, also creates a difficulty for the judges of the ECtHR, because ${ }^{4}$ they have to analyse all cases under both provisions and verify which of these provisions is more relevant in each individual factual situation. If complaints are better targeted, it would save important resources and consequently allows a jurisdiction to handle these urgent, because involving the parental authority, custody or access, cases more effectively.

Finally, this article aims to provide arguments to scholars studying Articles 6 and 8 ECHR.

\section{Research methodology}

This research study is based on the analysis in the HUDOC database of ECtHR cases involving the right to a fair trial in family relationship cases. The research method aims to include all relevant cases on Articles 6 and 8 taking into account the research question. The HUDOC database provides the opportunity to find all cases involving Articles 6 and 8 examined by the ECtHR. The number of results in the HUDOC database is indicated below: 1504 cases include Articles 6 and 8 ECHR (Alston, Goodman 2013; ECtHR 2017 HUDOC User Manual). ${ }^{5}$

The research results have shown all cases involving Articles 6 and 8, even if there is no explicit allegation under one of these articles and the article is only mentioned in the text of the judgment. ${ }^{6}$

\footnotetext{
${ }^{2}$ According to the ECtHR, the conflicting decisions of domestic supreme courts are in breach of the fair trial requirement enshrined in Article 6 para 1 of the Convention (ECtHR Perez Arias, para 25; ECtHR Ştefan and Ştef, paras 33-36; ECtHR Schwarzkopf and Taussik), if 'profound and long-standing differences' exist in the case-law of a supreme court. The existence of breach further depends whether the domestic law provides for machinery for overcoming these inconsistencies, whether that machinery has been applied and, if appropriate, to what effect (ECtHR, Iordan Iordanov and Others, paras 49-50).

${ }^{3}$ For the purposes of ensuring the quality and consistency of its case-law, the Court is also assisted by a Jurisconsult (ECtHR 2020, Rules).

${ }^{4}$ Statement based on the comparative research table of the ECtHR case law involving Articles 6 and 8 attached in the annex to this article.

${ }^{5}$ The HUDOC database is available at hudoc.echr.coe.int (visited 5 April 2019).

${ }^{6}$ For example, the applicant raised the allegation before the ECtHR under Article 10 and not Article 8 ECHR in case Alpha Doryforiki Tileorasi Anonymi Etairia. The Court however mentioned Article 8 examining a fair balance between the applicant's right to freedom of expression under Article 10 and his legal opponent's right to reputation, which is a part of the right to private life, as protected under Article 8 of the Convention. In the same case, the applicant complained about the right to a fair trial without undue delay and the Court found a violation under Article 6. Consequently, the case comes up as a research result for Article 6 and Article 8, but it is irrelevant for the research because in reality Article 8 is not at stake in the above-mentioned ECtHR judgment Doryforiki Tileorasi Anonymi Etairia.
} 


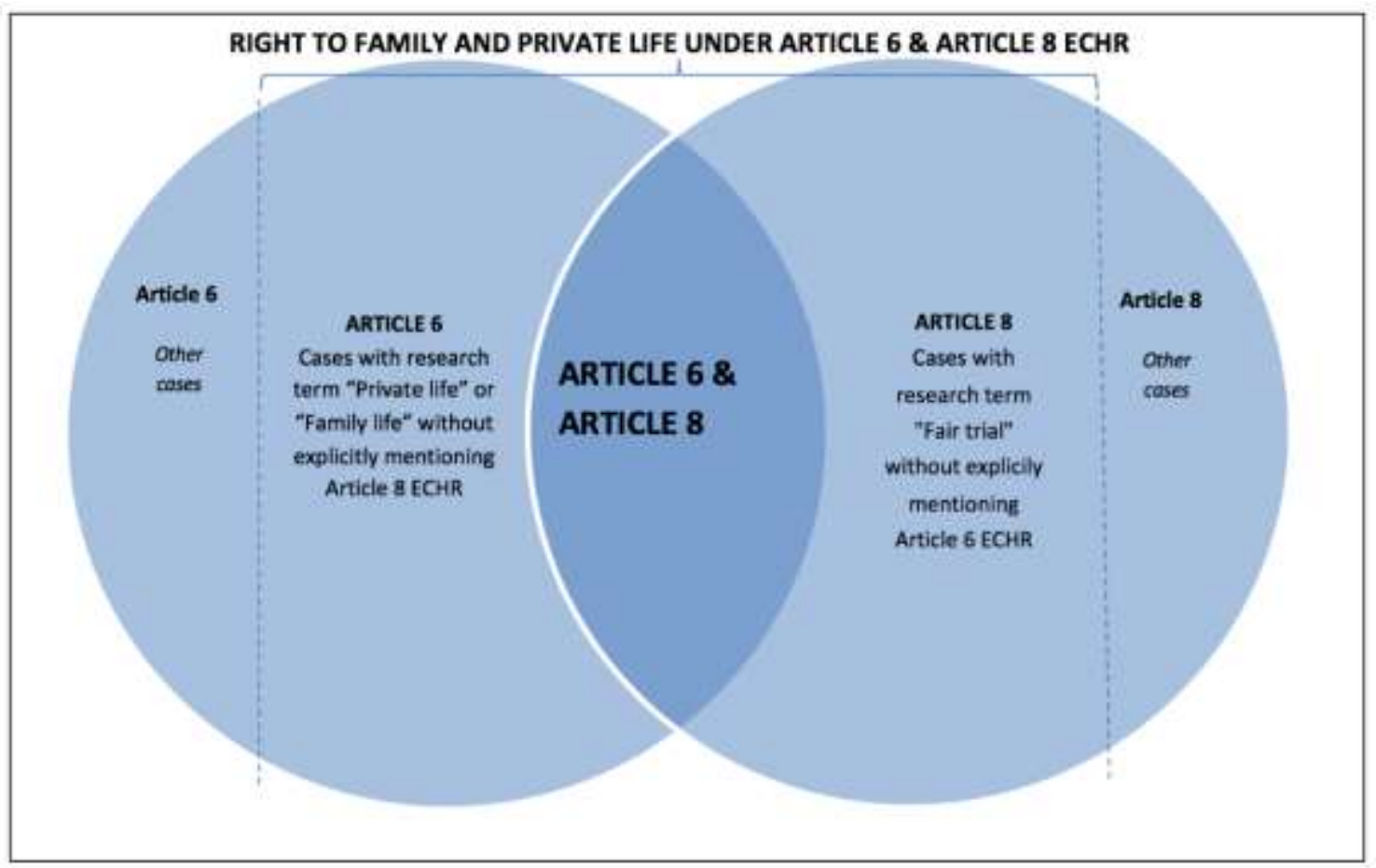

Figure 1. The graphic representation of the interplay between Article 6 and Article 8 ECHR

Source: Self-plotted diagram.

This research study is based on the first group of cases involving family life. ${ }^{7}$ It focuses on parent-child relationship cases, and more specifically parental authority (without child abduction), parental custody and access rights. It does not examine filiation (paternity claims and adoption).

To find cases providing the information needed in order to answer the research question, the non-technical selection criteria (substantive, procedural and temporal) were used. The results were restricted to the judgments which involve Article 6 para 1 AND Article 8 para 1 (1504 hits on 1 November 2018) and the keywords 'Respect for family life' OR 'Respect for private life' (1161 hits on 1 November 2018).

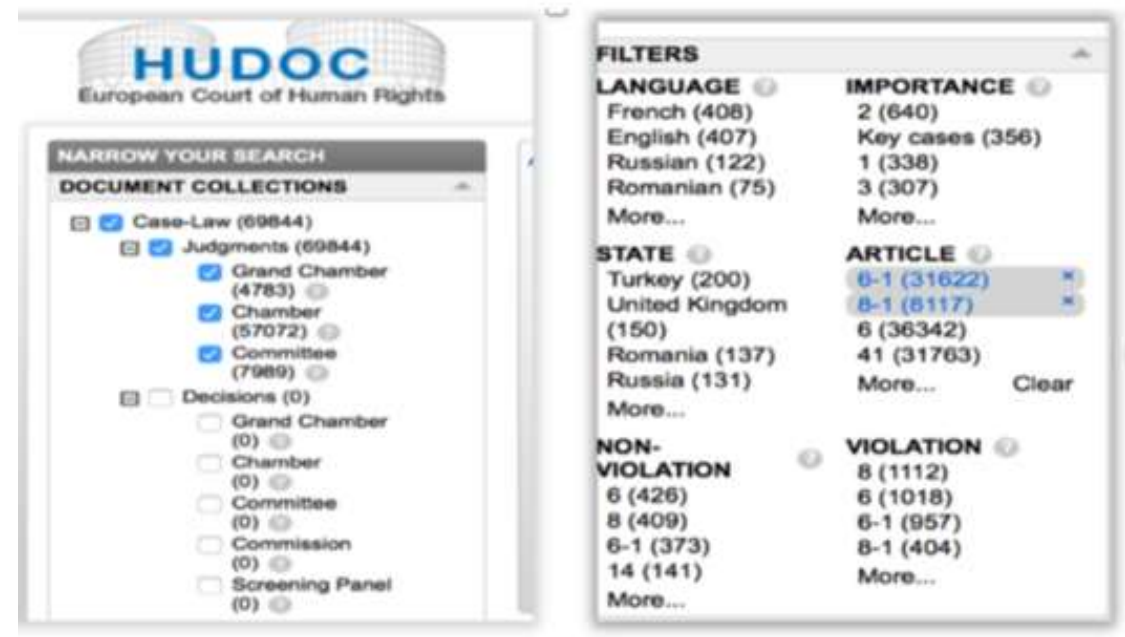

Figure 2. Step 1 and 2: Judgement and filters Article 6-1 and 8-1

Source: Own screenshot. Data: HUDOC database.

\footnotetext{
${ }^{7}$ Research table including ECtHR cases on parental authority, parental custody and access rights figures in the annex to this article.
} 

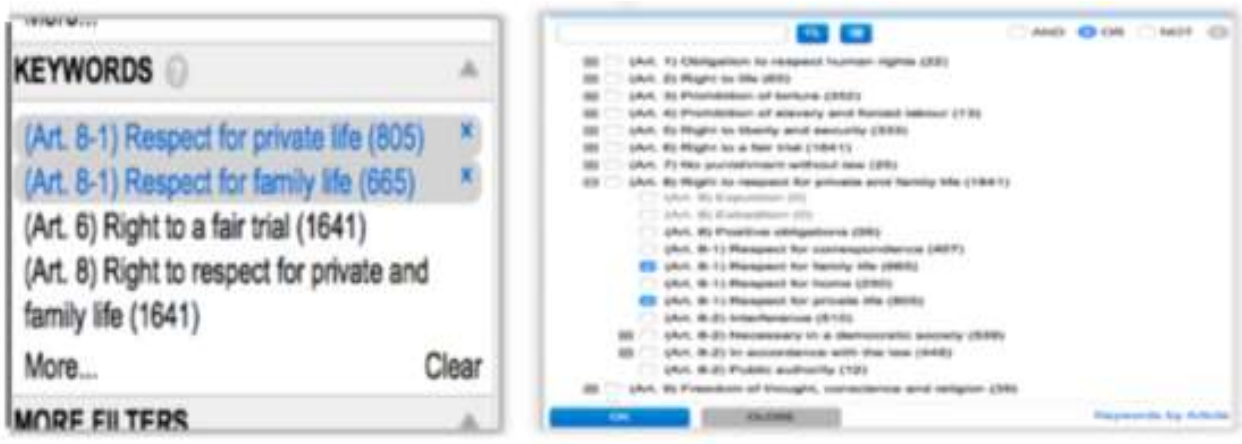

Figure 3. Step 3: Keywords Respect for provate life or Respect for family life

Source: Own screenshot. Data: HUDOC database.

Next, the temporal limits were established. The research covers a period of nearly twenty years, which seems to be a reliable sample for this research (1998-2018). Therefore, the judgments before 1 November $1998^{8}$ were removed (1108 hits on 1 November 2018). Finally, some irrelevant cases, which appeared as a result of errors in the HUDOC database were also eliminated. ${ }^{9}$

Furthermore, to select the relevant cases for the research question, the technical selection criteria were used: Initially, the research was restricted by language: English OR French (459 hits on 1 November 2018). In this way, all translations of cases into other languages were eliminated from the research results and the judgments available in English OR French have been kept for further research. At this stage, however, the research results also covered the cases available in English AND French. These cases are mainly Grand Chamber cases, which are regularly translated into the second language. Consequently, these French duplicates still had to be eliminated in the later research process. Now, the superfluous hidden metadata-only documents (ECtHR 2017 HUDOC User Manual $)^{10}$ were taken out of the research results (406 hits on 1 November 2018). Finally, the above-mentioned French duplicates were eliminated. For this, the list of all preselected judgments was exported in an Excel document. In case of judgments in English and in French, the French version of the judgment was manually deleted in each case (212 hits on 1 November 2018).

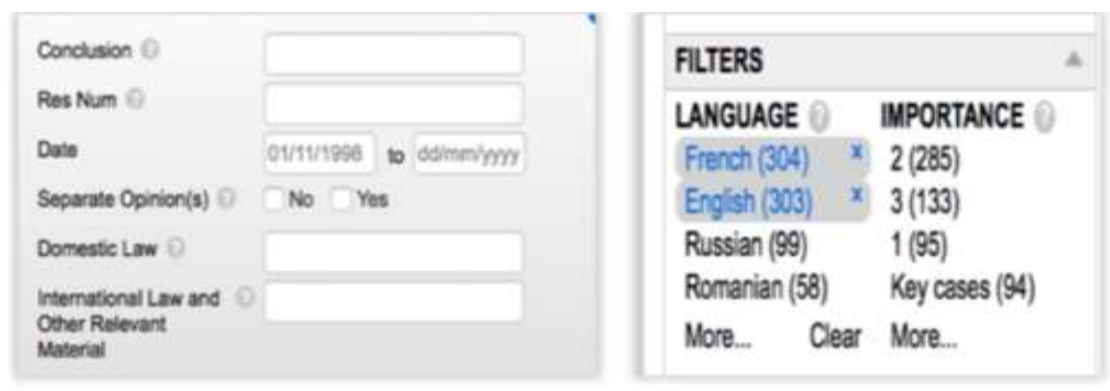

Figure 4. Step 4 and 5: Date from 01/11/1998 and language French and English

Source: Own screenshot. Data: HUDOC database.

\footnotetext{
${ }^{8}$ On 1 November 1998, Protocol No. 11 replaced the existing, part-time ECtHR and ECmHR by a single, full-time Court. The right to submit a direct individual application by any person, non-governmental organisation or group of persons has been established in Article 34 of the Protocol. The research was conducted on 1 November 2018, so it covers ECtHR judgments delivered in the last twenty years.

${ }^{9}$ Example of miscellaneous cases irrelevant for the research: 1. Unilateral declarations (ECtHR, Vereshchagin and Others; ECtHR, Lück; ECtHR, Kalanyos and Others); 2. Friendly settlements (ECtHR, Draon; ECtHR Maurice; ECtHR, Jonasson); 3. Cases on Article 10 and 6 with reflections on Article 8 in the context of freedom of expression (ECtHR, Satakunnan Markkinapörssi Oy and Satamedia Oy; ECtHR, Alpha Doryforiki Tileorasi Anonymi Etairia; ECtHR, Bédat); 4. Cases with reference to Article 6 and no reference to Article 8, which should not have to appear in the research (ECtHR, Przydziat); Cases with reference to Article 8 and no reference to Article 6, which should not have to appear in the research (ECtHR, Rodrigues Da Silva and Hoogkamer).

${ }^{10}$ According to Tech Target which provides the definitions of IT terms, the document metadata is: '(...) information attached to a text-based file that may not be visible on the face of the document; documents may also contain supporting elements such as graphic images, photographs, tables, and charts, each of which can have its own metadata', more information is available at the website: https://whatis.techtarget.com/definition/document-metadata (visited 7 July 2019).
} 


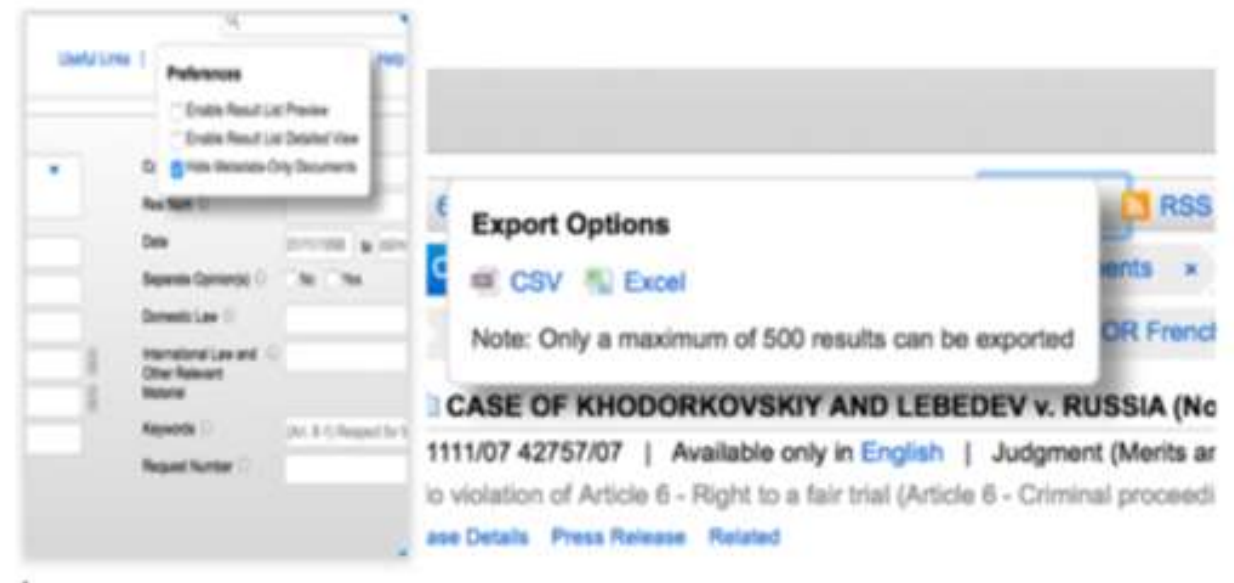

Figure 5. Step 6: Hide metadata only documents and export in Excel

Source: Own screenshot. Data: HUDOC database.

The research revealed 212 relevant cases, which still involved either the 'Right to private life' or the 'Right to family life'. As a next step, the 212 cases were divided into two groups: the first group of 118 cases concerning the right to family life and the second group of 119 cases concerning the right to private life. Some rare cases are in both groups, because they involve the right to private life as well as the right to family life. That is why these two groups do not add up to 212 .

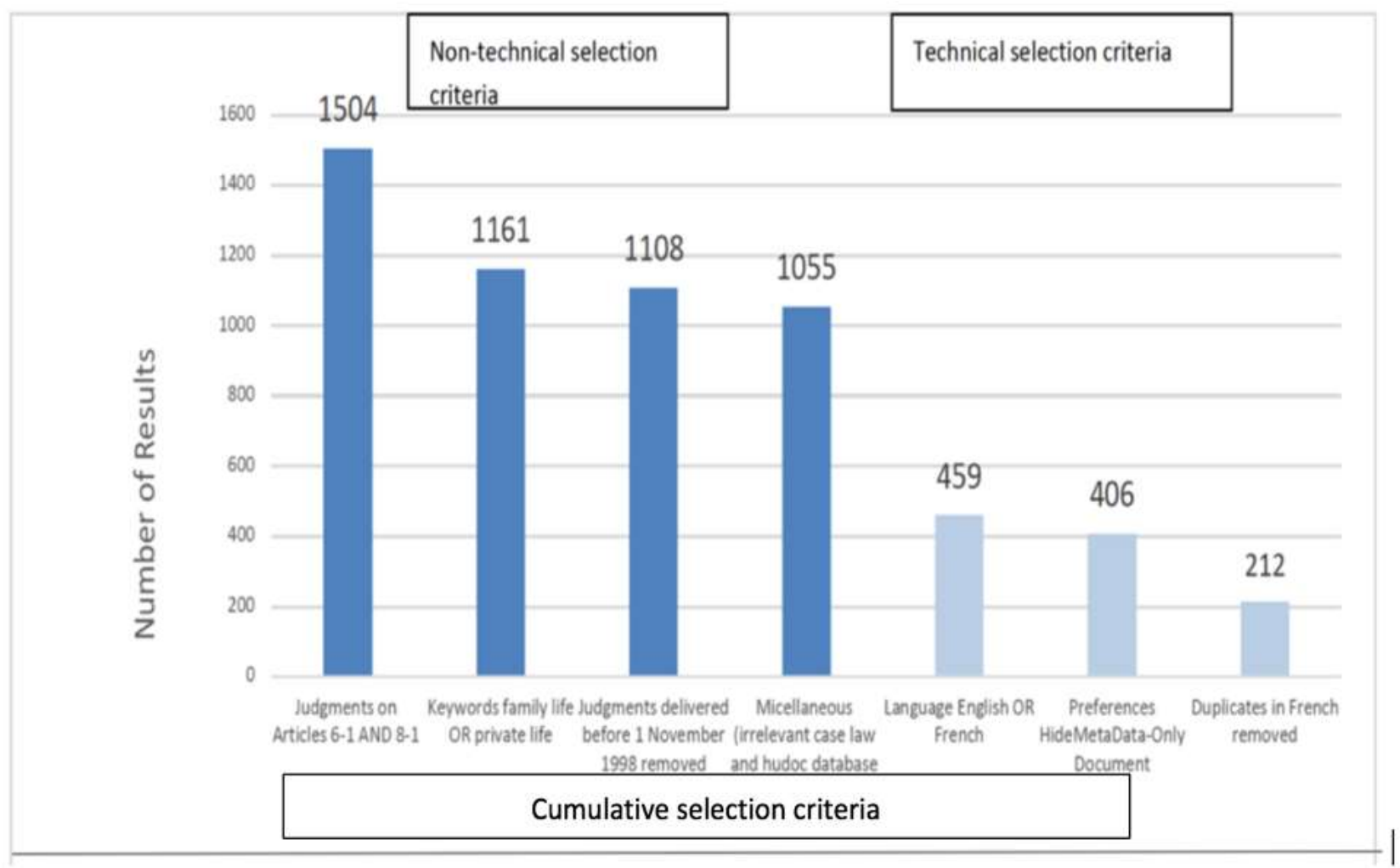

Figure 6. Right to a fair trial and right to private life and family life in HUDOC database. Research on 1 November 2018

Source: Self-plotted bar graph. Data: HUDOC database. 


\section{Analysis and interpretation of research results}

\subsection{Parental responsibilities vis-à-vis parental authority, custody and access/contacts. The terminology used for data classification.}

Varied terminology is used to describe different aspects of the parent-child relationship. That is why its understanding is explained below.

Parental authority, for the needs of this article, should be understood as a parental right to physical custody, supervision, physical and psychological protection, health and safety, education, providing food and caring for the children. Custody means physical custody exercised by parents, which is 'the care of the person of the child, including the right to decide on the place of his residence' (Council of Europe, European Convention on Recognition and Enforcement of Decisions concerning Custody of Children and on Restoration of Custody of Children 1980). The access/contact rights are a kind of parental access/contact with a child and having all the necessary information about him/her (ECtHR 2019 Guide on Article 8). ${ }^{11}$

For a better understanding of the meaning of parent-child relationships, the interdependence of parental authority, parental custody, and access/contacts can be visualized. A parent who has the right to custody and/or the parental authority has always access to a child/contacts. However, the parent having neither the right of parental custody nor parental authority can also have a right of access to a child/contacts.

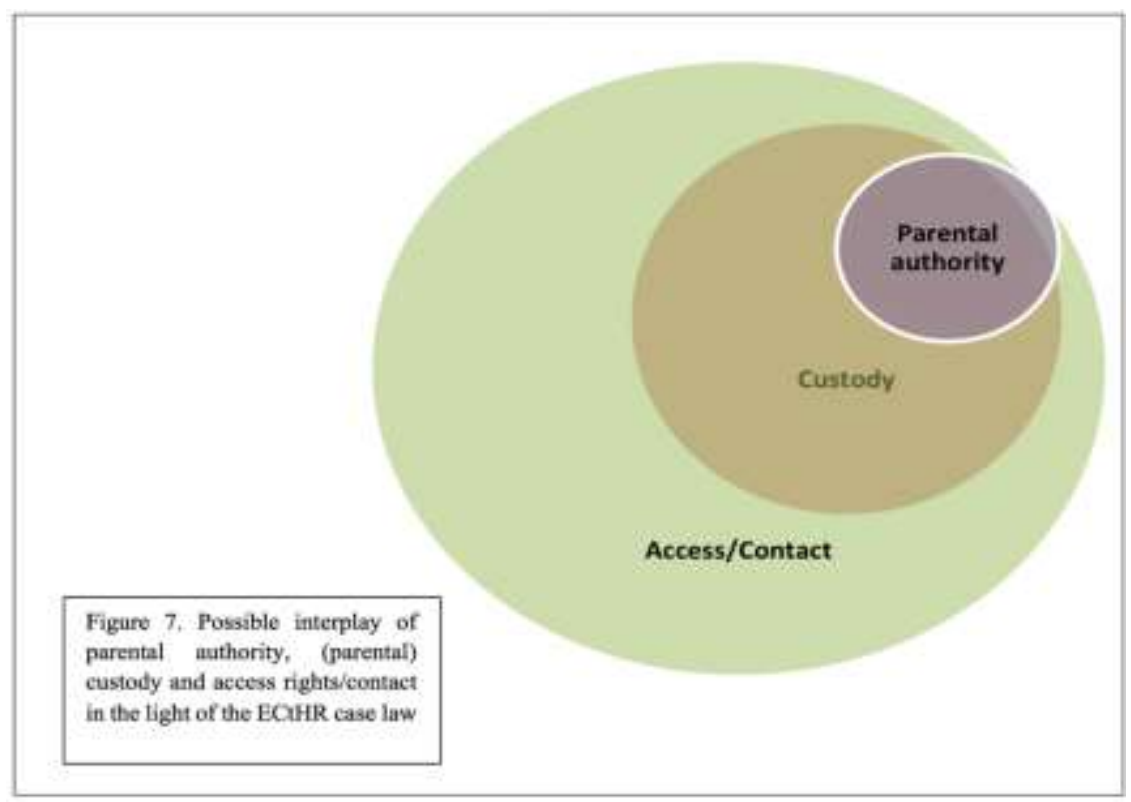

Source: Self-plotted diagram. Data: HUDOC database.

The terminology used in this article will follow the terminology used by the ECtHR because firstly this article focuses on the ECHR.

Secondly, this choice makes it possible for the detailed data classification and consequently the more precise conclusions of the research study to be obtained. Instead of one big group of cases involving parental responsibilities, the research results are classified into three groups of cases: parental authority, parental custody, and access/contacts. This detailed data classification makes it possible to determine the rules

\footnotetext{
11 The right to maintain contact is protected as a child's right in the Convention on the Rights of the Child, Article 9 para 3: "States Parties shall respect the right of the child who is separated from one or both parents to maintain personal relationships and direct contact with both parents on a regular basis, except if it is contrary to the child's best interests." Article 24 para 3 of the EU Charter of Fundamental Rights is constructed in a similar way and express a child's right to maintain contact: 'Every child shall have the right to maintain on a regular basis a personal relationship and direct contact with both of his or her parents unless that is contrary to his or her interests.' However, the ECtHR affirms, under Article 8 ECHR, that 'the mutual enjoyment by parent and child of each other's company constitutes a fundamental element of family life' (ECtHR, $K$. and T.). Despite the fact that this right can be limited by the best interests of the child, this right is at the "centre of judicial decision-making about custody of and contact with children" (EU FRA/ECtHR/Council of Europe Handbook on European law relating to the rights of the child 2015). The right of contact is thus treated as a child's right, but also as a parental right.
} 
established by the ECtHR for each of these three groups of cases and to identify the eventually existing patterns for each of them.

Consequently, without a good understanding of the terms parental authority, parental custody and access/contacts, the understanding of the whole research study risked being undermined.

\subsection{Results regarding parental authority cases}

\subsubsection{Introduction}

Parental authority is the strongest parental right in ECtHR terminology. It covers the parental right to take the major and day-to-day decisions in respect of the child, the parental duty of care and the physical custody.

Among the research results are ten judgments related to parental authority (called in two cases alternatively parental rights, but classified as parental authority cases having account of the rights at stake in these cases) involving Articles 6 and 8. These cases can be grouped respectively under four substantive family rights. In nine cases, the applicants raised allegations under both Articles 6 and 8. In one case the applicant raised a complaint under Article 8, but he committed a procedural mistake and complained under Article 6 instead of Article 13. However, the Court analysed the case ex officio under Article 6 (ECtHR, Assunção Chaves).

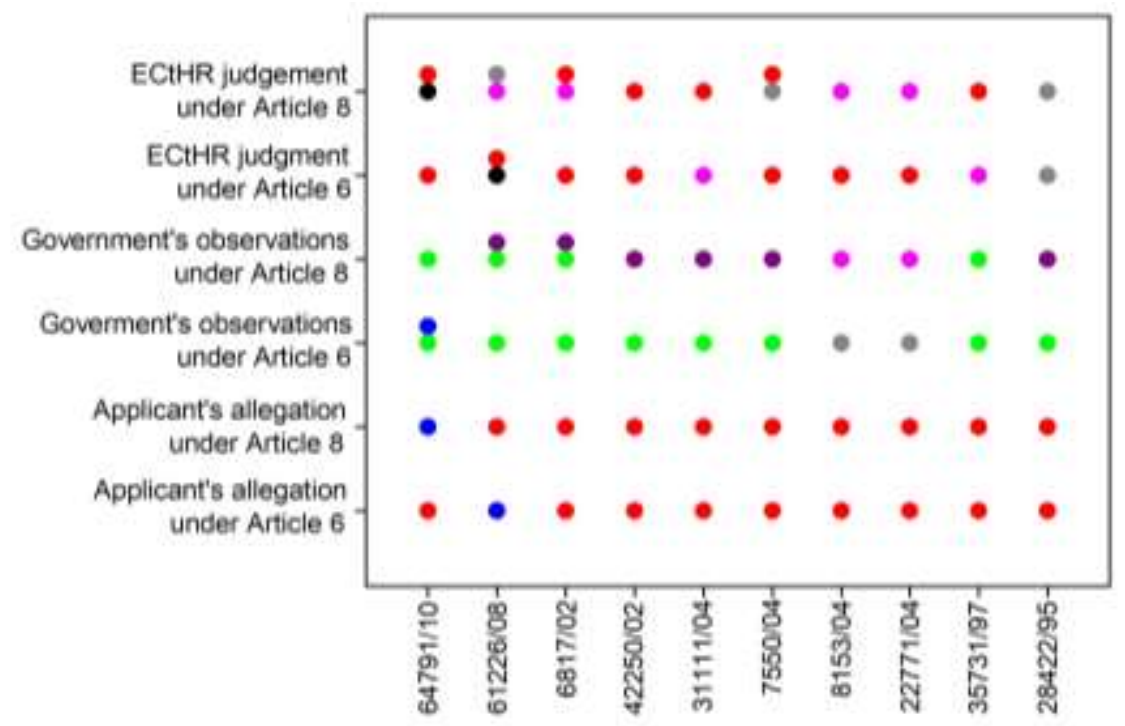

\footnotetext{
- Not appicabie OR Allegaion not raised by the appicant OR No observations from the Govemment

Viobion: Raised in the applicants alegation OR Recognized by the Covernment in their observations OR Found by the ECrha in the judgement No violation: No vioiation aroved by the Government OR No violation found by the ECHR

No vielason. Interference in Appicans s Privase of Farsily Life considered as Justified by Covernmers

Inadmissbie: Alegatian inadmissibie according to the Covernirent OR Alegation inadmissbie according to the ICEHR

Examined ex afficie by the ECriR wetheu the Government opposition

Not necessary to examine the alegation under the examined articio OR No separate issue under the examined article
}

Figure 8. The graphical representation of ECtHR case-law: Parental authority cases involving Article 6 and Article 8 ECHR

Source: Self-plotted scatter plot. Data: HUDOC database.

\subsubsection{Parental authority cases of a violation of Articles 6 and 8}

The ECtHR found a violation of Articles 6 and 8 in four cases concerning parental authority, three out of these four cases are relevant for this research. ${ }^{12}$ It will be verified below if a violation of both Articles was related to parental authority.

\footnotetext{
${ }^{12}$ In Calmanovici v Romania (ECtHR, Calmanovici), a suspect was placed in pre-trial detention and deprived of parental authority during the imprisonment. The allegation under Article 6 was related to the right to be heard in criminal proceedings and under Article 8 to the deprivation of parental authority. This case is not taken into consideration since it concerns different procedures for which the violations under Articles 6 and 8 have been accepted by the Court.
} 
In M.D. and Others v Malta (ECtHR, M.D.), the Court examined the automatic and perpetual deprivation of parental authority; taking children into public care following a criminal conviction of the parent for illtreatment of his children; as well as the lack of access to a court to challenge this decision at a future date. It decided that these allegations were well-founded and failed to strike a fair balance between the interests of the children, those of the applicant and those of society at large. This measure was not 'necessary in a democratic society' for the aforesaid aim and was in breach of Articles 6 and 8. The Government submitted that the complaint under Article 6 is inadmissible for non-exhaustion of domestic remedies. It also raised that Article 6 was not applicable to these proceedings, because a care order issued in the public interest for the protection of a minor was a public law matter and did not concern civil rights and obligations. In answer to this argument, the Court stated that: 'the mutual enjoyment by parent and child of each other's company constitutes a fundamental element of family life (...) Thus, an action to contest a care order (...) is a matter of family law. On that account alone, it is 'civil' in character (...). It is therefore indisputable that a dispute in respect of a care order falls under the civil limb of Article 6' (ECtHR, M.D. para 43).

In Iordache v Romania (ECtHR, Iordache), the applicant complained under Article 8 (and 13) about the ban on exercising parental authority resulting from his imprisonment. He further complained under Article 6 about the inability to exercise remedies in proceedings for access to a child because of the non-payment of a fee. The Court found these two allegations well-founded and concluded that there had been a violation of Articles 6 and 8 (and 13). The interesting point, in this case, is the fact that the applicant also complained under Article 8 about the lack of contact/visitation rights with the child. However, the Court decided that it is not necessary to examine this allegation, because it has already found a violation in respect of parental authority under Article 8. This means that the Court considers the right to contact as a part of parental authority and it does not need to analyse it separately.

In Reslová v the Czech Republic (ECtHR, Reslovà), under Article 6 para 1 of the Convention, the Court found that the duration of the procedure relating to the exercise of parental authority had not met the requirement of a 'reasonable time'. Under Article 8, the Court found that the competent authorities did not make adequate and sufficient efforts to enforce the provisional decision on parental authority for both parents. They did not facilitate the applicant's diligent reunification with her children and, thus, the Court concluded that there had been a breach of Article 8. Besides, under Article 8, the Court did not find a violation concerning the final refusal of the right to custody to the applicant.

\subsubsection{Parental authority cases of no violation of Articles 6 and 8}

The ECtHR found no violation of Articles 6 and 8 in one case. In Hoppe v Germany (ECtHR, Hoppe) the Court found that 'the procedural requirements implicit in Article 8 of the Convention were complied with and that the applicant was involved in the decision-making process to a degree sufficient to provide him with the requisite protection of his interests' (ECtHR, Hoppe paras 65-66). Consequently, it decided that: 'viewing the domestic judicial proceedings as a whole, the Court finds no breach of Article 6 para 1 of the Convention as regards the alleged unfairness of the proceedings and the lack of an oral hearing before the (...) Court of Appeal' (ECtHR, Hoppe paras 65-66).

\subsubsection{Parental authority cases of a violation of Article 8 and no need to examine allegations under Article 6}

The ECtHR found a violation of Article 8 and no need to examine allegations under Article 6 in two cases. In Hunt v Ukraine (ECtHR, Hunt), the applicant was banned from entering the country in which proceedings leading to deprivation of his parental rights/authority ended without him having been heard. The Court found that: 'the lack of respect for the applicant's family life resulting from the non-involvement of the applicant in the (...) proceedings is at the heart of his complaint. Therefore, having regard to its above findings under Article $8(\ldots)$, the Court considers that it is not necessary to examine the facts also under Article 6' (ECtHR, Hunt para 66). In Venema $v$ the Netherlands (ECtHR, Venema) the Court found that the taking of a provisional care order without providing parents with the opportunity to contest it was in violation of Article 8 . The Court observed that: 'the applicants' complaints under Article $6(\ldots)$ largely coincide with their complaints under Article 8. The Court does not find it necessary to examine the facts also under Article 6 para 1 of the Convention' (ECtHR, Venema para 101). 


\subsubsection{Parental authority cases of a violation of Article 6 and no need to examine allegations under Article 8}

The ECtHR found a violation of Article 6 and no need to examine allegations under Article 8 in three cases. In Maršálek v the Czech Republic (ECtHR, Maršálek) the ECtHR found a violation of the right to a fair trial without undue delay under Article 6 in respect of proceedings related to parental authority. The Court did not examine the allegation under Article 8: ' (...) in light of the finding relating to Article 6 para $1(\ldots)$, the Court considers that there is no need to consider whether there has been a violation of this provision in this case (...). Moreover, the impact of the duration of the disputed procedure on the applicant's family life was taken into account in the context of the issue of the procedure for the assessment of the duration of the proceedings' (ECtHR, Maršálek para 55). The situation is similar in Cambal v the Czech Republic (ECtHR, Cambal) where the ECtHR found a violation of the right to a fair trial without undue delay under Article 6 in respect of proceedings related to parental authority. The Court did not examine the allegation under Article 8: 'in light of the findings relating to Article 6 para 1 (...), the Court considers that there is no need to consider whether there has been a violation of this provision in this case (...). On the other hand, the impact of the duration of the disputed procedure on the applicant's family life was taken into account in the context of the procedural issue' (ECtHR, Cambal para 38).

In Assunção Chaves $v$ Portugal (ECtHR, Assunção Chaves), the ECtHR found a violation of Article 6 and no need to examine allegations under the procedural limb of Article $8 .{ }^{13}$ Regarding the procedural limb of Article 8, the Court found that: ' $(\ldots)$ while Article 8 does not contain any explicit conditions of the procedure, the decision-making process relating to the measures of interference must be fair and appropriate to respect the interests protected by that provision. Therefore, depending on the circumstances of each case and in particular the seriousness of the measures to be taken, it is necessary to determine whether the parents were able to play a part in the decision-making process as a whole; a role large enough to grant them the necessary protection of their interests. If not, there is a breach of respect for their family life and the interference resulting from the decision cannot be regarded as 'necessary' within the meaning of Article 8 (...). The Court considers that, in view of the conclusions it has reached with regard to the violation of Article 6 para 1 of the Convention, it is not necessary to proceed to a separate examination of the case under Article 8 of the Convention from a procedural point of view' (ECtHR, Assunção Chaves paras 108-109).

\subsubsection{Conclusion}

The cases involving procedural issues - fairness, access to a court, and involvement in decision-making which have an impact on parental authority are examined by the ECtHR under both Articles 6 and 8 and, where well-founded, it finds a violation of both of them (ECtHR, M.D.; ECtHR, Iordache). In parallel, there are other cases concerning the same procedural issues, in which the ECtHR examined the allegations under Article 8 and it stated that it is not necessary to analyse them under Article 6 (ECtHR, Hunt; ECtHR, Venema). This choice is justified by the Court very briefly, stating that it does not analyse the allegation under Article 6 'having regard to its findings under Article 8' (ECtHR, Koudelka para 75). or because 'the complaints under Article 6 largely coincide with the complaints under Article 8' (ECtHR, Venema para 101).

The situation is clearer in cases of parental authority involving the right to a fair trial without undue delay. Here, the Court examines the complaints mainly under Article 6 and it states that it is not necessary to analyse them under Article 8 (ECtHR, Maršálek; ECtHR, Cambal para 38; ECtHR, Assunção Chaves).

In some cases, involving procedural issues other than the undue delay, the ECtHR finds a violation based on both provisions: Articles 6 and 8 (ECtHR, Reslová).

In conclusion, the ECtHR analyses the procedural rights related to parental authority under Article 8, and less often, under both provisions, Articles 6 and 8. The right to a fair trial without undue delay is the only procedural aspect related to parental authority cases analysed by the ECtHR as a matter of Article 6, and less often under both provisions, Articles 6 and 8 .

\footnotetext{
${ }^{13}$ In Assunção Chaves, the ECtHR also found a violation of the substantive limb of Article 8, but the research interest focuses on the interplay between Articles 6 and 8, which in this case was related to the procedural ambit of Article 8 .
} 


\subsection{Results regarding parental custody cases}

\subsubsection{Introduction}

A child's physical custody is the parental duty of care provided to a child on a daily basis and, in a case of divorce, the child's residency arrangements.

Among the analysed ECtHR judgments, there are eighteen judgments related to the right to parental custody. Ten of these eighteen judgments concern the excessive length of proceedings (the right to a fair trial without undue delay). ${ }^{14}$ Eight other judgments are related to other aspects of the right to a fair trial in custody cases.

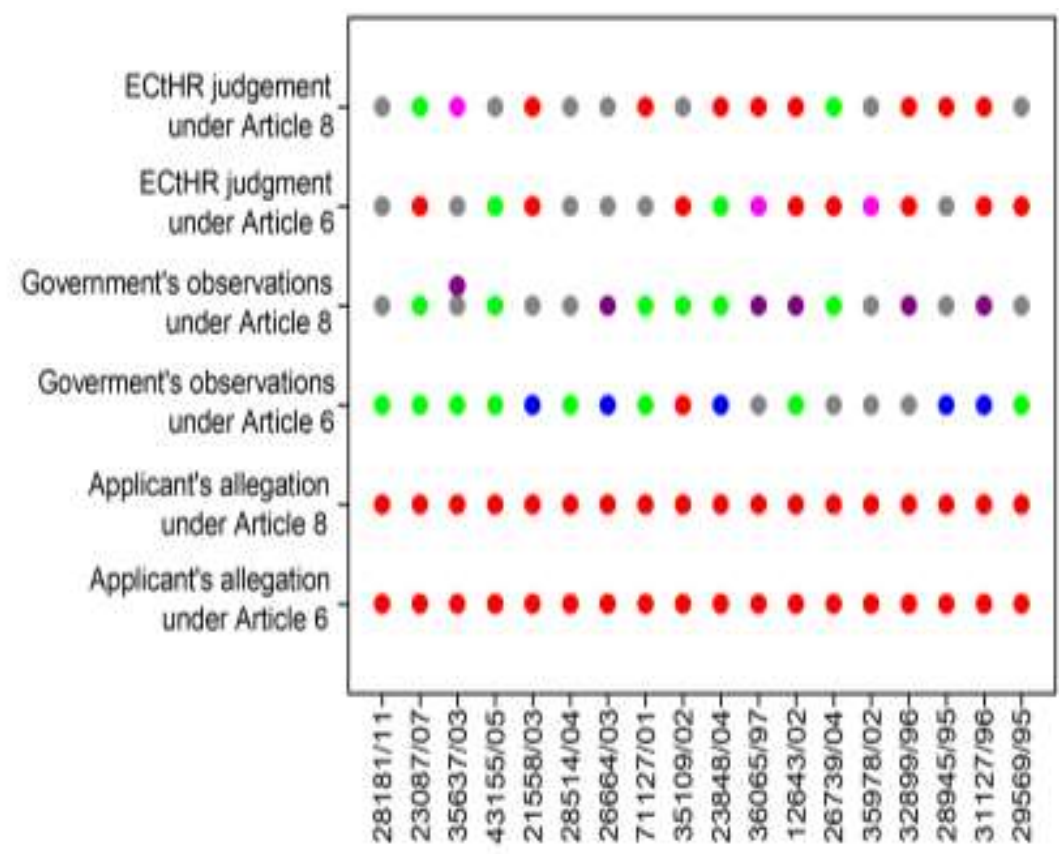

\footnotetext{
- Not applicable OR Alegation not rised by the appicant OR No observations from the Governmert

Volation: Raisod in the applicant's alegation OR Rocognized by the Goverment in their obsensators OR Found by the ECHAR in the judgement

No volation No volation argued by the Govemment OR No violation found by the ECIHR

No violation, Interforence in Applicant's Private of Family Life considered as Justifed by Govemment

inadmissible: Alegation nadmissible accorting to the Govermment OR Allegation inadmissible according to the ECtHR

Not recessary to examine the alegatien under the esamined arficio OR No separate issue under the examined article
}

Figure 9. The graphical representation of ECtHR case-law: Parental custody cases involving Article 6 and Article 8 ECHR

Source: Self-plotted scatter plot. Data: HUDOC database.

5.3.2. Parental custody cases on the right to a fair trial without undue delay

In all ten cases involving the right to a fair trial without undue delay, applicants raised both provisions Articles 6 and 8 ECHR.

Firstly, there is a group of cases in which the ECtHR did not find a violation of Article 6 nor did it find a violation of Article 8. The ECtHR found no violation of Article 6 and it decided that, in Zdravković v Serbia (ECtHR, Zdravkovic) as well as in Ancel v Turkey (ECtHR, Ancel) there was no violation of Article 8. In Mihailova v Bulgaria (ECtHR, Mihailova) the Court decided that there was no violation of Article 8 and it was not necessary to analyse the allegation under Article 6. In Z. v Slovenia (ECtHR, Z.), the allegation under Article 6 was inadmissible and the ECtHR found no violation of Article 8.

\footnotetext{
14 'The reasonable time requirement is a separate guarantee which is not to be seen simply as part of the overriding right to a fair trial' (Amos 2014).
} 
The cases involving a violation of one of the ECHR provisions (Article 6 or 8) are more relevant for this research and the analysis of the interplay between these two provisions. In Veljkov v Serbia and Dostál v the Czech Republic (ECtHR, Veljkov, ECtHR, Dostál), the ECtHR found a violation of Article 6 and, under Article 8, declared the complaint inadmissible.

In Veljkov v Serbia, the main lawsuit for parental custody/maintenance continued for an excessively long time and prevented the applicant from exercising her parental rights/custody. This allegation was analysed under Article 6. The non-enforcement of an access/contacts order issued by the Court was examined under Article 8 in light of respect for the applicant's family life.

In Dostál v the Czech Republic, the ECtHR analysed the applicant's allegation on the excessive length of parental custody proceedings under Article 6. Under Article 8, the Court examined the allegation that the national authorities, by their inactivity, prevented the applicant from exercising his right to access/contact during the overall length of the custody proceedings.

In the above cases, involving either a violation of Article 6 or Article 8, the ECtHR analysed a different issue under each of the Articles. The applicants' allegations related to the right to a fair trial without undue delay were examined by the ECtHR under Article 6 and the allegations related to the right to family life were examined by the ECtHR under Article 8 .

Secondly, in two cases, the ECtHR found a violation of Article 8 and declared, respectively, no violation (ECtHR, Bevacqua and S.) and inadmissibility (ECtHR, Wallová and Walla) of allegations under Article 6.

In Bevacqua and S. v Bulgaria (ECtHR, Bevacqua and S.), the applicants complained under Article 6 about the length of the custody proceedings, but the ECtHR found no violation of this provision. Under Article 8, the ECtHR decided that: ' $(. .$.$) a failure to adopt interim custody measures without delay in a situation which$ adversely affected the applicants (...) amounted to a failure to assist the applicants contrary to the State positive obligations under Article 8 of the Convention to secure respect for their private and family life' (ECtHR, Bevacqua and S. para 84).

In Wallová and Walla $v$ the Czech Republic (ECtHR, Wallová and Walla), the applicants complained that: 'they had been separated from their children and complained of a lack of assistance from the national authorities. In this regard, they relied on Articles 1, 6, 8 and 13 of the Convention and Article 1 of Protocol No. 12. Having discretion with respect of the legal classification of the facts of the claim, the Court considers it appropriate to examine the complaints raised by the parties concerned only from the perspective of Article 8 , which requires that the decision-making process leading to interference measures must be fair, as appropriate, respect the interests protected by this provision (...)' (ECtHR, Wallová and Walla para 47). Under Article 6, the applicants raised concerns that 'the length of the proceedings concerning their children had breached the principle of 'reasonable time' as provided for in Article 6 para 1 of the Convention'. The Court found that this allegation was manifestly ill-founded because the proceedings were complex and the courts acted at a rapid pace. Indeed, the proceedings lasted almost three years for three courts, two of which ruled on several occasions (ECtHR, Wallová and Walla para 80).

Thirdly, in E.P. v Italy and Mincheva v Bulgaria (ECtHR, E.P., ECtHR, Mincheva), the ECtHR found a violation of both provisions Article 6 as well as Article 8. In E.P. v Italy, the ECtHR found a violation of Article 6, because of the excessive length of parental custody proceedings. Under Article 8, the Court found that: 'the authorities dealing with the case, albeit enjoying a margin of appreciation, failed to take all necessary steps, which could be reasonably expected of them in the circumstances, to ensure that the chances of the applicant and her daughter re-establishing their relationship should not be definitively compromised' (ECtHR, E.P. para 69). In Mincheva v Bulgaria, the findings of the Court were the same as in E.P. v Italy.

In conclusion, in all ten cases involving the right to a fair trial without undue delay, the applicants raised an allegation of the excessive length of parental custody proceedings under Article 6 and the Court analysed it under Article 6. All complaints under Article 8 in these cases were related to procedural issues other than the length of proceedings. There was no case in which the ECtHR analysed the allegation of the excessive length of proceedings ex officio under Article 6. The pattern in cases involving the right to a fair trial without undue delay in parental custody proceedings is that the complaint should be submitted and analysed under Article 6 of the Convention. 
Based on the above-mentioned research results, the question on what happens if Article 6 has not been invoked and if the Court then does or does not use Article 8 ex officio to analyse the allegation of the excessive length of proceedings cannot be answered. However, the Court has already examined the authorities' inactivity and the excessive length of enforcement proceedings related to the custody of a child solely under Article 8 (ECtHR, Santos Nunes paras 54-56) when Articles 6 and 8 were both invoked.

\subsubsection{Parental custody cases on the involvement of the applicants in the decision-making process}

In all eight cases involving other aspects of the right to a fair trial, applicants raised both provisions -Articles 6 and 8 ECHR.

There are three cases related to the involvement of the applicants in the decision-making process about parental custody.

In Sporer $v$ Austria (ECtHR, Sporer), the ECtHR found no violation of Article 6 and found it not necessary to analyse the allegation under Article 8. In H.K. v Finland (ECtHR, H.K.), the ECtHR found no necessity to analyse the allegation under Article 6, but it concluded that there had been a violation of Article 8. In two cases (ECtHR, Moser; ECtHR, Buchberger), there was a violation of both provisions, Articles 6 and 8 .

In Sporer $v$ Austria, the applicant complained that he had not received a proper hearing under Article 6 of the Convention, in particular, because he was not heard by the district court. He further complained under Article 8, taken alone and in conjunction with Article 14, that the relevant provisions of the Civil Code and their application by the courts had discriminated against him as the father of a child born out of wedlock.

In H.K. $v$ Finland, the applicant made various complaints under Articles 6 para 1 and 8 of the Convention. The applicant argued in particular that depriving him of parental custody and taking the child into public care was against the child's best interests. He further complained that access restrictions had been issued. He was informed many months after he had been accused of suspected abuse, and his request for the audio-tapes was refused. The ECtHR found a violation of Article 8 because the child was placed away from the applicant in the absence of a formal decision to that effect; in respect of the restrictions on access on four occasions; and as regards the applicant's other complaints. It considered that: 'the complaints made by the applicant under Article 6 are a restatement of his complaints about the absence of procedural guarantees allowing him to be associated with the decision-making process. It has analysed those complaints under Article 8 of the Convention as regards both the taking into care proceedings and the restriction on access proceedings above and considers that, in the circumstances of this case, it is not required to examine them separately from the standpoint of Article 6' (ECtHR, H.K. para 124).

In Moser v Austria, the applicants complained that the transfer of custody of the child to the Youth Welfare Office violated their right to respect for family life as guaranteed by Article 8 of the Convention. Under Article 6 , they alleged a lack of a public hearing and a lack of any public pronouncement of the decisions. The Court found a violation of Article 6 on account of the failure to pronounce the courts' decisions publicly.

In Buchberger $v$ Austria, the applicant complained that the decision of the Regional Court transferring custody of her sons to the Youth Welfare Office amounted to a breach of Article 8 of the Convention. Under Article 6 , she further complained that the appeal proceedings were unfair because the Regional Court relied on fresh evidence of which she had not been informed and, thus, had no opportunity to react thereto. The Court made a statement: 'Having regard to the considerations under Article 8, the Court finds that there has also been a violation of Article 6 para 1 in the present case in that the Regional Court relied on evidence of which the applicant had not been informed' (ECtHR, Buchberger para 51).

Among cases related to the involvement of the applicants in the decision-making process about parental custody, there were Sporer v Austria and Moser v Austria, which, apart from the fact that they confirmed that the procedural rights are raised and examined by the Court under Article 6, have not brought any new element to this research. However, an interesting observation can be made in two other cases, H.K. v Finland and Buchberger $v$ Austria. In the first case, the ECtHR explains that, in relation to the procedural issues having been examined under Article 8, it is not necessary subsequently to examine the allegation under Article 6 . In the second case, the ECtHR outlined that, taking account of a breach of procedural rights under Article 8, it has reached the conclusion that there was also a violation of Article 6.

5.3.4. Parental custody cases on the access to a court 
In three cases, the applicants complained that they had been denied the right of access to court in parental custody proceedings. Access to court is one of the most important aspects of the right to a fair trial, because 'the detailed fair-trial guarantees under Article 6 would be useless if it were impossible to start court proceedings in the first place' (Robin, White, Ovey 2010; ECtHR, Golder).

In K.T. v Norway (ECtHR, K.T.), the ECtHR found neither a violation of Article 6 nor a violation of Article 8. The applicant complained under Article 8 that: '(..) the investigations carried out by the child welfare services, despite a first such investigation showing that his former wife's allegations were groundless, had constituted an unjustified interference with his right to respect for private and family life under Article 8 of the Convention. He further raised his procedural allegations under Article 8: (...) dismissal of his case by the Norwegian courts, and hence their refusal to review the merits of his case, he had been denied access to a court (...), in breach of Article 6 (...) of the Convention (...)' (ECtHR, K.T. para 47).

In answer to these allegations, raised under Article 8, the Court clearly stated that the examination: 'under the above provision will be limited to the applicant's complaint about the child welfare services' second investigation into his ability to assume the care for his two sons'. Under Article 6, the applicant complained that 'the summary dismissal of his case by the City Court and the High Court, whose decision was later upheld by the Supreme Court, violated his right of access to a court' (ECtHR, K.T. para 71). In this particular case, the Court analysed this allegation in meriti and concluded that there had been no violation of Article 6.

In Schmidt v France (ECtHR, Schmidt) there was a violation of Article 6 and no violation of Article 8. In this case, the applicants complained under Article 6 that they were deprived of custody of their daughter because of their religion. They raised procedural allegations under Article 6, in particular about the length of the proceedings and that they did not have access to the Advocate General's conclusions and to the rapporteur's report before the Court of Cassation in breach of their right to a fair trial. The ECtHR analysed all procedural issues under Article 6 of the Convention.

In T.P. and K.M. v the UK (ECtHR, T.P. and K.M), on the contrary, there was no violation of Article 6, but a violation of Article 8. Under Article 8, the applicants complained that the child had been unjustifiably removed from her mother in violation of their right to respect for family life. Invoking Article 6, the applicants complained that they had been denied access to court in the determination of their claims of negligence against the local authority. The Court examined the allegation related to the right of access to court under Article 6 .

\subsubsection{Parental custody cases on the impartiality of the judge}

In one case, the impartiality of the judge in charge of custody proceedings was at stake for the applicants. The impartiality of the court means a 'lack of prejudice or bias' (Harris, O'Boyle, Bates, Buckley, et al. 2018).

In Buscemi v Italy, the ECtHR found a violation of Article 6 and no violation of Article 8. Under Article 6 , the ECtHR stated: '(from) the fact that the President of the court publicly used expressions which implied that he had already formed an unfavourable view of the applicant's case before presiding over the court that had to decide, it clearly appears incompatible with the impartiality required of any court, as laid down in Article 6 para 1 of the Convention' (ECtHR, Buscemi para 68).

Under Article 8, the Court found no violation in respect of two allegations: the fact, according to the applicant, the national court had based its decision, according to the applicant, on an expert report which was unfounded and procedurally flawed; injury caused to the reputation of the applicant and that of the applicant's family because the opinion of the judge had been published in the press before the trial.

To sum up, the impartiality of the court is clearly a matter related to Article 6.

\subsubsection{Conclusion}

In parental custody cases involving the right to a fair trial without undue delay, the allegation is raised by the applicants and is examined by the Court under Article 6 of the Convention. In custody cases related to the involvement in the decision-making process, the procedural issues are in principle raised by the applicants and examined by the ECtHR under Article 6. However, in two cases the ECtHR examined the procedural issues under Article 8 and decided that it is not necessary to examine them under Article 6. The right to access to a court and an impartial judge are clearly procedural matters raised by the applicants and examined by the 
ECtHR under Article 6. Consequently, Article 6 is the main procedural guarantee for the litigants in the parental custody proceedings before the ECtHR.

\subsection{Results regarding access/contact cases}

\subsubsection{Introduction}

Contact between children and their parents is a fundamental element of family life (Keller 2016). Access/contacts is a parent's bundle of rights or times and days during which he/she has time with the child and having all the necessary information about the child.

The research revealed twenty-six cases involving the right of access to a child among cases examined by the ECtHR under Articles 6 and 8 by the ECtHR: there were twelve cases on the deprivation or restriction of access rights; thirteen cases concerned the non-enforcement of legally existing right of access to a child; thirteen cases were related to the excessive length of access proceedings (Rajska, 2016); five cases concerned the right to a fair trial.

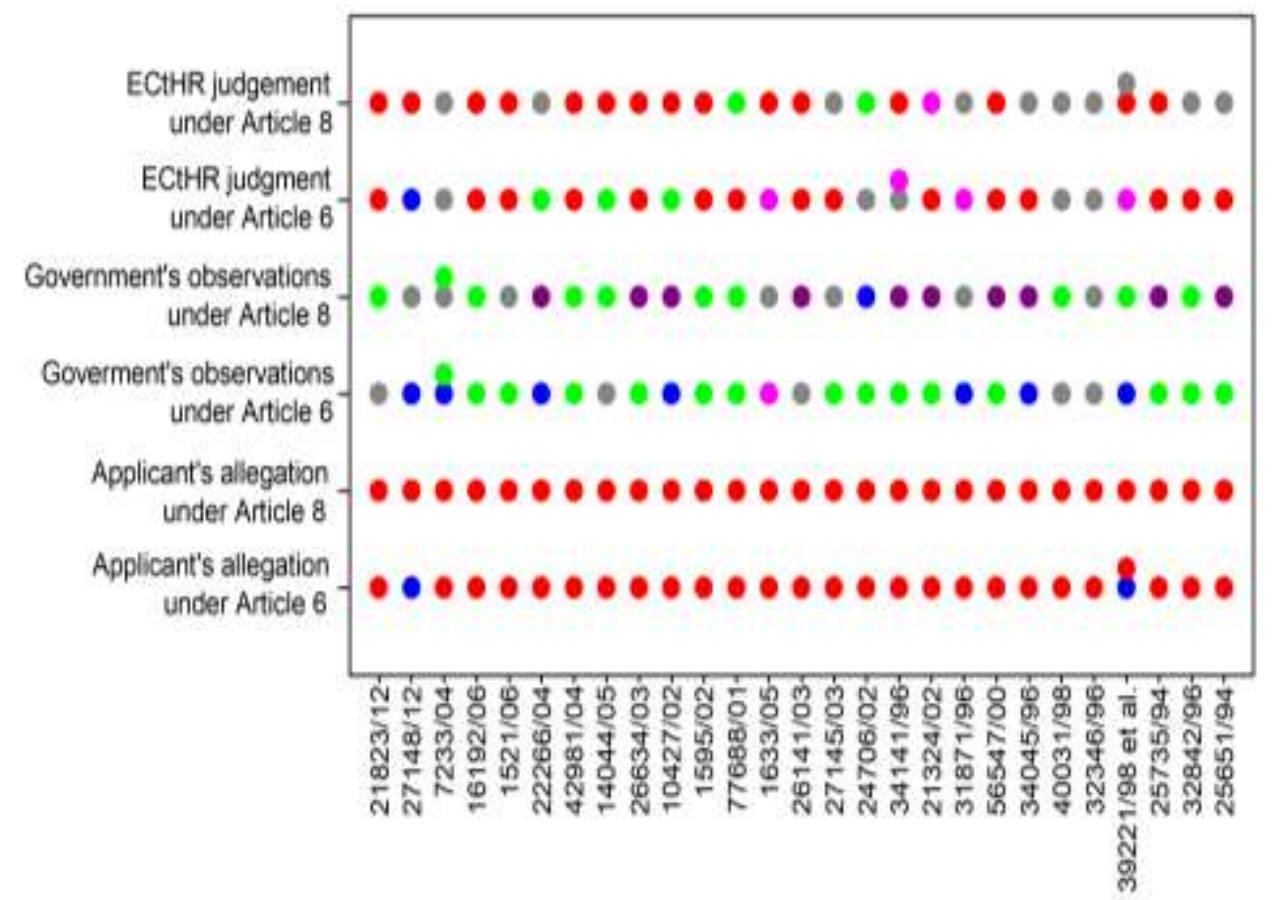

\footnotetext{
LEGEND
- Not apolicable OR Alegation nox raised by the applicant OR No obeervations from the Government

- Not apolicable OR Alegation not rased by the applicant OR No observations from the Government
Violation. Raised in the appicant's alegation OR Recogrized by the Goverment in ther obsarvations OR Found by the ECtHR in the judgamen

- No volation: No viclaton argued by the Govemment OR No violation found by the ECHR

- No violatian interference in Appicant's Privale of Family Lite consoded as Justified by Gavernment

Inadmissible: Allegation inadmissible according to the Government OR Allegation inadmissble according to the ECIHR

Not necessary to examine the allegation under the examined aticle OR No saparate issue under the examined article
}

Figure 10. The graphical representation of ECtHR case-law: Access to a child/contact cases involving Article 6 and Article 8 ECHR

Source: Self-plotted scatter plot. Data: HUDOC database.

5.4.2. Cases on deprivation or restriction of access rights

Among twelve cases on the deprivation or restriction of access rights, there are seven cases in which the allegation was raised under Article 8 and in which the ECtHR found a violation of Article 8 (ECtHR, Tsikakis, Roda and Bonfatti; ECtHR, R. v Finland; ECtHR, P., C. and S.; ECtHR, Sommerfeld; ECtHR, Scozzari and Giunta; ECtHR, Elsholz). In one of them, Sommerfeld v Germany, in light of its findings under Article 8 alone and taken together with Article 14, the ECtHR did not find it necessary to examine separately the applicant's complaints under Articles 6 and 14 of the Convention (ECtHR, Sommerfeld para 100). In Scozzari and Giunta $v$ Italy, the European Commission on Human Rights ('ECmHR') stated that the complaint under Article 6 para 1 about the length of the proceedings should be regarded as having been absorbed by issues related to 
Article 8 of the Convention. The Court saw no reason not to follow the conclusions of the ECmHR on this point and accordingly held that no separate issue arises under these provisions of the Convention (ECtHR, Scozzari and Giunta paras 229-230).

Finally, in $R$. v Finland (ECtHR, R. para 108), the Court found a violation of Article 8 of the Convention. In light of this conclusion, it did not find it necessary to examine, as a possible separate source of the violation, whether the applicant received a fair hearing (under Article 6) (ECtHR, R.).

In four cases, in which the applicants complained under Article 8, the ECtHR found no violation of this article (ECtHR, Rytchenko; ECtHR, Hoffmann; ECtHR, Gnahoré; ECtHR, L.). In one of these cases, Hoffmann v Germany, under Article 8, the ECtHR found a breach of the applicant's access rights and it found that the applicant was not sufficiently involved in the decision-making process as required under Article 6 (ECtHR, Hoffmann para 63). In Lubina v Slovakia, the applicant complained under Article 8, and the ECtHR declared this allegation inadmissible (ECtHR, Lubina).

In conclusion, deprivation or restriction of access rights is an issue raised by the applicants and examined by the ECtHR under Article 8 of the Convention.

\subsubsection{Cases on non-enforcement of a legally existing right of access to a child}

In thirteen cases, the non-enforcement of a legally existing right of access to a child was raised by the applicants and examined by the ECtHR under Article 8. In seven out of thirteen cases, the ECtHR concluded that there had been a violation of Article 8 (ECtHR, Stasik; ECtHR, Cengiz Kiliç; ECtHR, Övüş; ECtHR, Zavřel; ECtHR, Křržz; ECtHR; Koudelka; ECtHR, Fiala). In one of these cases, Zavřel v the Czech Republic (ECtHR, Zavřel), the applicant relied on Article 8 and Article 6 para 1 and alleged that his requests for enforcement of his right of access were not examined fairly and within a reasonable time, and that his right to respect for his family life was violated by the non-execution of the judgment on access rights. The Court recalled that: 'It has (...) ruled in the past that, while Article 8 of the Convention does not contain any explicit conditions of the procedure, the decision-making process leading to interference must be fair and adequately respect the interests protected by the Convention. (...) Thus, as regards the procedure for enforcing access, the Court sees no reason to depart from (its previous) approach (...)' (ECtHR, Zavřel para 32). Further, in the same paragraph of the judgment, the Court consequently referred to the case of 'Kř́žz v Turkey (ECtHR, Kř́žz para 32), in which it found it useful to consider the duration and conduct of such a procedure (for enforcing access) under Article 8 of the Convention'(ECtHR, Zavřel para 32). In one case, Koudelka v the Czech Republic, the ECtHR decided that: 'Accordingly, and having regard to its finding of a violation of Article 8, the Court considers that it is not necessary to consider the applicant's allegations separately under Article 6 of the Convention' (ECtHR, Koudelka para 75).

In four cases (ECtHR, Gobec; ECtHR, Pedovič; ECtHR, Glaser; ECtHR, Nuutinen), the ECtHR did not find a violation of Article 8. In the first of them, Gobec $v$ Slovenia, 'the applicant referred to Articles 6 and 8 of the Convention, complaining in substance about the excessive restriction and, subsequently, suspension of his contact rights, the non-enforcement of the contact schedule and the delays in the divorce, parental custody and maintenance proceedings, and the administrative and non-contentious child contact proceedings. The Court, being the 'master of the characterization' to be given in law to the facts of any case before it (...), considered that these complaints are closely linked and fall to be examined under Article 8 of the Convention' (ECtHR, Gobec para 105).

In Rylski v Poland (ECtHR, Rylski), the ECtHR declared an allegation under Article 8 inadmissible for nonexhaustion of domestic remedies. The allegation under Article 6, in this case, was related to the excessive length of divorce proceedings and was not linked to the enforcement of access rights.

Plasse-Bauer v France (ECtHR, Plasse-Bauer) is the only case revealed by the research in which the ECtHR examined the allegation of the non-enforcement of access rights under Articles 6. The Court recalled: 'its consistent jurisprudence that Article 6 para 1 of the Convention also protects the implementation of final and binding judicial decisions which, in a State which respects the rule of law, cannot remain inoperative to the detriment of a party. Consequently, the execution of a judicial decision cannot be prevented, invalidated or delayed in an excessive manner. (...) the execution of a court order granting a parent access to his child requires urgent treatment, as the passage of time may have consequences irremediable on the relationship between the child and the parent who does not live with him (...)' (ECtHR, Plasse-Bauer paras 45-46). 
Concerning Article 8, the ECtHR concluded that: 'the complaint raised by the applicant under Article 8 of the Convention largely coincides with that of Article 6 of the Convention. (...) it considers that no separate issue arises under Article 8 of the Convention. Accordingly, the Court considers that it is not necessary to examine whether there has been a violation of this provision in this case (...)' (ECtHR, Plasse-Bauer paras 70-71).

This case should, however, be treated as incidental. The ECtHR justified the examination of the allegation and the finding of a violation under Article 6 using a reference to the case-law not related to family law (ECtHR, Plasse-Bauer para 45), in particular cases involving: administrative proceedings to open language schools (ECtHR, Hornsby); proceedings against social security for compensation payment (ECtHR, Burdov); restoration of property rights to a plot of land (ECtHR, Jasiünienè); and a request to demolish a building partially built on the applicant's land (ECtHR, Ruianu).

Taking into account the above, it is clear that the Court's approach in Plasse-Bauer was more general than in other family cases. It is true that the enforcement of judgments is most often a matter for Article 6 . However, the research clearly shows that the allegation of the non-enforcement of judgments related to family cases, including access rights to a child, is examined under the procedural ambit of Article 8 of the Convention (mutatis mutandis Article 1 of Protocol No. 1 in respect of property rights). Consequently, the pattern is that the allegation of the non-enforcement of cases on access rights to a child is raised by the applicants and examined by the ECtHR under Article 8.

\subsubsection{Cases on excessive length of access proceedings}

In nine of the thirteen cases related to the excessive length of access proceedings, the allegations were raised by the applicants and examined by the ECtHR under Article 6 (ECtHR, Tsikakis; ECtHR, Övüsş; ECtHR, Křžz; ECtHR, Fiala; ECtHR, Pedovič; ECtHR, R.; ECtHR, Glaser; ECtHR, Scozzari; ECtHR, Nuutinen).

In two cases, both provisions were raised by the applicant, but the Court examined the allegation of the excessive length of proceedings only under Article 8, and decided that it was not necessary to examine it or rejected the application as manifestly ill-founded under Article 6 (ECtHR, Koudelka; ECtHR, Zavřel).

In two of the thirteen cases, the allegation was raised by the applicant under Article 8 instead of Article 6, and the ECtHR analysed it under the procedural limb of Article 8 finding a violation in Ribić v Croatia (ECtHR, Ribić) and no violation in Pedovičv the Czech Republic (ECtHR, Pedovič).

Consequently, as in the case of parental authority and custody, the allegation of the excessive length of proceedings is an issue raised by the applicants and examined by the ECtHR mainly under Article 6. The Court will examine this allegation of the excessive length of proceedings under the procedural scope of Article 8 if the applicants do not raise it under Article 6 of the Convention.

Concerning the five cases on the right to a fair trial, they are related to various issues, which were always raised by the applicants under Article 6 .

Non-involvement in the decision-making process was at stake in $L$. (ECtHR, L.) (lack of oral hearing) and in Elsholz v Germany (ECtHR, Elsholz) (failure to obtain an expert opinion in respect of child access, failure to hold a hearing on appeal) and resulted in both cases being in violation of Article 6.

In one case, the ECtHR found no violation of the right to legal aid in access proceedings (ECtHR, Gnahoré). In this case, the allegation involving restrictions on access rights to a child in care was examined by the ECtHR under Article 8. In Hoffmann v Germany, the Court found no violation of access rights to a child but a violation of the right of access to a court in access-rights proceedings (ECtHR, Hoffmann).

In Roda and Bonfatti $v$ Italy, the ECtHR found a violation of access rights to a child under Article 8 and rejected as inadmissible (not submitted within six months after the end of the proceedings) the allegation of a lack of access to a court in access-rights proceedings under Article 6 (ECtHR, Roda and Bonfatti).

In $P$., $C$. and $S$. $v$ the $U K$ (ECtHR, $P$., $C$. and $S$.) the Court found a violation of access rights to a child in care under Article 8 and a violation of the right to a fair trial because of a lack of legal representation in proceedings concerning child care and access rights.

\subsubsection{Conclusion}


The procedural issues in parent-child relationship cases involving Articles 6 and 8, in particular the decisionmaking process, the legal aid and the access to court are clearly matters which are raised by the applicants and examined by the ECtHR under Article 6 of the Convention.

\section{General conclusion}

The main aim of the article is to answer the following research question:

'In parent-child relationship cases involving Articles 6 and 8 ECHR, are there clear guidelines for the application of these provisions by the European Court of Human Rights?'

To answer this question, the study was based on the in-depth analysis of 212 judgments involving Articles 6 and 8 ECHR in cases of a parent-child relationship, more particularly: parental authority, parental custody and access to a child. Additionally, this research allowed for the classification of all analysed cases in accordance with the examined issues: the right to a fair trial, the right to a fair trial without undue delay and the nonenforcement of judgments. This detailed classification makes it easier to determine and to present the existence of eventual guidelines on the application of Articles 6 and 8 ECHR.

\section{The right to a fair trial.}

In some parental authority cases related to fairness or access to a court, the ECtHR finds a violation of both Articles 6 and 8. In parallel, in some of them, the ECtHR finds a violation of Article 8 and decides that it is not necessary to examine allegations under Article 6.

In parental custody proceedings, the alleged breach of the right to be involved in the decision-making process is generally raised by the applicants and examined by the ECtHR under Article 6. On some rare occasions, the Court analyses this allegation under Article 8. Access to a court and the impartiality of the judge are analysed under Article 6.

In proceedings related to access to a child, the procedural issues of involvement in the decision-making process, legal aid and access to a court are clearly matters which are raised by the applicants and examined by the ECtHR under Article 6 of the Convention.

\section{The right to a fair trial without undue delay.}

In cases involving the right to a fair trial without undue delay in parental authority, custody, and in proceedings related to access to a child, the general trend is to raise the allegation of the excessive length of proceedings and examine it under Article 6 of the Convention. The ECtHR examines the excessive length of proceedings under Article 8 only in very rare cases, mostly when the applicants do not raise this allegation under Article 6.

\section{Enforcement of judgments.}

The non-enforcement of judgments is related to access rights to a child. These cases are examined by the ECtHR under the procedural ambit of Article 8 of the Convention.

We can note from the research study that the ECtHR classifies an allegation ex officio, respectively under Article 6 or 8 , if it decides that such a provision is more adequate. This situation, in which the allegation is not clearly raised by the applicant under the relevant provision but examined by the ECtHR under such a provision, enables the Government concerned to make an objection (ECtHR 2020, Rules of Court). However, the research study did not reveal a single case in which any Government had objected to the classification of the merits of the case under a provision other than the one raised by the applicant in parent-child relationship cases involving Articles 6 and 8 before the ECtHR. ${ }^{15}$

The ECtHR has a lot of importance because it is the highest European jurisdiction and it delivers binding judgments against 47 Member States. A judgment delivered against one Member State is, following the principle of res judicata, implemented in that State, but it is also respected in the other Member States

\footnotetext{
${ }^{15}$ Examples of the cases in which the ECtHR analysed ex officio the allegation under, respectively Articles 6 and 8, without the objection of the Government: Assunção Chaves and M.D. and Others.
} 
following the principle res interpretata (Bodnar 2013). Consequently, a judgment delivered for example against Turkey becomes the origin of reforms in France (ECtHR, Salduz).

How should an applicant effectively lodge a parent-child relationship case involving Articles 6 and 8 before the ECtHR? The below conclusions are made to serve as guidelines for the applicants, legal professionals, and scholars.

This thorough analysis of the parent-child relationship cases lodged before the ECtHR makes it possible to draw the following conclusions concerning the application of Articles 6 and 8:

Article 6 is clearly the most relevant provision for complaining about the excessive length of proceedings before the ECtHR. Article 8 is certainly the most relevant provision for complaining about the nonenforcement of judgments in cases concerning access to a child.

In cases concerning access to a child and parental custody, the procedural issues such as fairness, access to a court or involvement in the decision-making process are in principle analysed under Article 6. In parallel, the same procedural issues in parental authority cases are analysed under Article 8. Here, the ECtHR explains that 'the procedural requirement of Article 8 does not only cover administrative procedures as well as judicial proceedings, but it is also ancillary to the wider purpose of ensuring proper respect for (...) family life' (ECtHR, Tapia Gasca paras 111-113; ECtHR, Bianchi para 112; ECtHR 2019 Guide on Article 8). Despite these arguments, it does not look as though parental authority would be more 'family right' than parental custody or the right of access to a child, but the choice of the provision lacks consistent justification.

Consequently, the Court processes the case by using in-depth and adequate analyse of the merits of parentchild relationship cases, and by using the above-mentioned guidelines in the application of Articles 6 and 8 for different groups of cases. In parallel, the ECtHR should probably more strongly justify the classification of the allegation under Article 6 or/and Article 8.

Also, this research study provokes and incites interested parties to reflect on the protection given under Article 6 or 8 ECHR. Which provision provides better protection for the applicants?

For example, Articles 6 and 8 require the exhaustion of different remedies before applicants can lodge their application at the ECtHR. The ECtHR probably makes a difference between the just satisfaction awarded to the applicants under Article 41 of the Convention in cases in which they complain under Article 6 as opposed to under Article 8. Possibly, there are also some differences in the procedure of the execution of ECtHR judgments, which conclude respectively a violation of Articles 6 and 8, by the Government concerned under the supervision of the Committee of Ministers of the Council of Europe. However, these questions cannot be answered in this article because they require an equally in-depth research project and analysis in connection with the question about the application of Articles 6 and 8 in parent-child relationship cases.

\section{Acknowledgments}

The author would like to thank Prof. Wendy Schrama, UCERF (Utrecht Centre for European Research into Family Law), Faculty of Law, Economics and Governance, Utrecht University, for her supervision during the postdoctoral stay and the anonymous reviewers who provided helpful comments on earlier drafts of the manuscript.

\section{References}

1. Alston P., Goodman R. (2013). 'Measuring and Evaluating Human Rights Performance' [in:] International human rights, Oxford University Press, pp. 1225-1277. https://www.academia.edu/38952337/International Human Rights

2. Bodnar A. (2013). Res interpretata: Legal Effect of the European Court of Human Rights Judgments from other States than those which were party to the proceedings, in: Haeck Y., Brems E. Human Rights and Civil Liberties in the $21^{\text {st }}$ Century, Springer Verlag, Heidelberg, 2013, p. 223. http://hdl.handle.net/1854/LU-4215793

3. Çali B. (2016). 'From flexible to variable standards of judicial review: Responsible domestic courts doctrine and ECtHR', [in:] Shifting Centres of Gravity in Human Rights Protection. Rethinking relations between the ECtHR, EU, and national legal orders, Arnardóttir O.M., Buyse A. (eds.), Routledge, pp. 144-160. DOI: https://doi.org/10.1017/S1574019616000018 
4. Costa J.P. (2008). 'The European Court of Human Rights: consistency of its case-law and positive obligations, Speech at Leiden University, 30 May 2008', [in:] Netherlands Quarterly of Human Rights, Vol. 26/3, p. 450. https://doi.org/10.1177/016934410802600308

5. Council of Europe/European Court of Human Rights, Guide on Article 8 of the European Convention on Human Rights, 2019, p. 13 (para 29), p. 14 (para 35), p. 60 (paras 286-293) available at: https://www.echr.coe.int/Documents/Guide_Art 8 ENG.pdf (visited 9 February 2020).

6. Council of Europe (1980), European Convention on Recognition and Enforcement of Decisions concerning Custody of Children and on Restoration of Custody of Children, Article 1 c), available at: https://rm.coe.int/1680078b09 (visited 13 July 2019).

7. Cremona J.J. (1990) 'The public character of trial and judgment in the jurisprudence of the European Court of Human Rights' [in:] Protecting Human Rights: The European Dimension: Studies in honour of Gérard J. Wiarda, Matscher F., Petzold H. (eds.), Carl Heymanns, Cologne. https://lib.ugent.be/catalog/rug01:000140380

8. European Union Agency for Fundamental Rights/European Court of Human Rights/Council of Europe (2015), Handbook on European law relating to the rights of the child, pp. 82, available at: https://fra.europa.eu/sites/default/files/fra_uploads/fra-ecthr-2015-handbook-european-law-rights-of-thechild_en.pdf (visited 24 February 2020).

9. European Court of Human Rights (2019), Annual Report 2019, p. 131: $84 \%$ of all applications lodged at the European Court of Human Rights are declared inadmissible, Available at https://echr.coe.int/Documents/Annual report_2019 ENG.pdf (visited 1 February 2020).

10. European Court of Human Rights (2020), Rules of Court, Article $18 \mathrm{~b}$ and 54, available at: https://www.echr.coe.int/Documents/Rules_Court_ENG.pdf (visited 20 February 2020).

11. European Court of Human Rights (2017), HUDOC User Manual, available at: https://www.echr.coe.int/Documents/HUDOC Manual ENG.PDF (visited 20 February 2020).

12. Garlicki L. (2010). 'Komentarz do art. 8. Prawo do poszanowania życia prywatnego i rodzinnego' [in:] Konwencja o Ochronie Praw Człowieka i Podstawowych Wolności, Vol. I, Komentarz do artykułów 1-18, Garlicki L. (ed.), C.H. Beck, p. 519. https://pdf.helion.pl/e_Ormv/e_0rmv.pdf

13. Harris D., O’Boyle M., Bates E.P., Buckley C.M., et al. (2018). 'Article 6: The right to a fair trial', [in:] Harris, O'Boyle \& Warbrick Law of the European Convention on Human Rights, 4th Edition, Oxford University Press, pp. 373-374. DOI: 10.1093/he/9780198785163.001.0001.

14. Hofmański P., Wróbel A. (2010). 'Komentarz do art. 8. Prawo do poszanowania życia prywatnego i rodzinnego' [in:] Konwencja o Ochronie Praw Człowieka i Podstawowych Wolności, Komentarz do artykułów 1-18, Vol. I, Garlicki L. (ed.), C.H. Beck, p. 270. https://pdf.helion.pl/e Ormv/e Ormv.pdf

15. Hofmański P., Wróbel A. (2010). 'Komentarz do art. 6. Prawo do rzetelnego procesu sądowego' [in:] Konwencja o Ochronie Praw Człowieka i Podstawowych Wolności, Vol. I, Komentarz do artykułów 1-18, Garlicki L. (ed.), C.H. Beck, p. 357. https://pdf.helion.pl/e Ormv/e Ormv.pdf

16. Keller H. (2016). 'Article 8 in the system of the Convention', [in:] Family forms and parenthood. Theory and practice of Article 8 ECHR in Europe, Büchler A., Keller H. (eds.), Intersentia, Cambridge-Antwerp-Portland, pp. 3-28. DOI: $10.1628 /$ rabelsz-2018-0022

17. Mole N., Harby C. (2006). The right to a fair trial: a Guide to the implementation of Article 6 of the European Convention on Human Rights, Human Rights Handbooks, No. 3, $2^{\text {nd }}$ edition, Strasbourg, as cited in Delcourt v Belgium App no 2689/65, para 25 (ECtHR, 17 January 1970), p. 5, available at: https://rm.coe.int/168007ff49 (visited 20 February 2020).

18. Quillere-Majzoub F. (1999). La défense du droit à un procès équitable, Bruylant, pp. $42-55$. https://www.academia.edu/6086700/LE_DROIT_A_UN_PROCES_EQUITABLE_ET_LE_JUGE_ADMINI STRATIF PAR FABIENNE QUILLERE-MAJZOUB

19. Rädler P. (1998). 'Independence and impartiality of judges', [in:] The right to a fair trial, Weissbrodt D., Wolfrum R. (eds.), Springer, pp. 727-746. http://hrlibrary.umn.edu/fairtrial/FairTrialBook.htm

20. Rainey B., Wicks E., Ovey C. (2014) 'The right to a fair trial in civil and criminal cases', [in:] Jacobs, White \& Ovey The European Convention on Human Rights, $6^{\text {th }}$ Edition, Oxford University Press, pp. 263-268. DOI: 10.1093/he/9780198767749.001.0001.

21. Rajska D. (2016). Comparative study of remedies against the excessive length of proceedings in Poland and in Serbia, Council of Europe, Belgrade. Available at: https://rm.coe.int/16806f0ef7 (visited 10 April 2019).

22. Rajska D. (2015). The right to a fair trial in France and in Poland, PUAM, France. https://rm.coe.int/16806f0ef7

23. United Nations (1989). Convention on the Rights of the Child, Article 9 para 3, available at: https://www.ohchr.org/en/professionalinterest/pages/crc.aspx (visited 24 February 2020). 
24. Vitkauskas D., Dikov G. (2017). Protecting the right to a fair trial under the European Convention on Human Rights, Council of Europe Human Rights Handbooks, $2^{\text {nd }}$ edition, Strasbourg, p. 11, available at: https://rm.coe.int/protecting-the-right-to-a-fair-trial-under-the-european-convention-on-/168075a4dd (visited 20 February 2020).

\section{ECtHR case law (complementary to the annexed table of ECtHR case law)}

1. Alpha Doryforiki Tileorasi Anonymi Etairia v Greece App no 72562/10 (ECtHR, 22 February 2018). https://hudoc.echr.coe.int/eng\#\{\%22itemid\%22:[\%22001-181295\%22]\}

2. Aresti Charalambous $v$ Cyprus App no 43151/04 (ECtHR, 19 July 2007).

3. Bédat v Switzerland [GC] App no 56925/08 (ECtHR, $29 \quad$ March 2016). https://hudoc.echr.coe.int/eng\#\{\%22itemid\%22:[\%22001-161898\%22]\}

4. Bianchi $v$ Switzerland App no 7548/04 (ECtHR, 22 June 2006). https://www.incadat.com/en/case/869

5. Burdov v Russia App no 59498/00 (ECtHR, 7 May 2002). https://hudoc.echr.coe.int/eng?i=001-60449

6. Draon v France [GC] App no 1513/03 (ECtHR, 6 October 2005). https://hudoc.echr.coe.int/eng?i=001-75905

7. G.B. v France App no 44069/98 (ECtHR, 2 October 2001).

8. Golder v the UK App no 4451/70 (ECtHR, 21 February 1975). https://hudoc.echr.coe.int/eng?i=001-57496

9. Gül v Switzerland App no 23218/94 (ECtHR, 19 February 1996). https://hudoc.echr.coe.int/eng?i=001-57975

10. Havelka and Others $v$ the Czech Republic App no 23499/06 (ECtHR, 21 June 2007).

11. Hornsby v Greece App no 18357/91 (ECtHR, 19 March 1997). http://echr.ketse.com/doc/18357.91-en-19970319/

12. Iordan Iordanov and Others v Bulgaria App no 23530/02 (ECtHR, 2 July 2009).

13. Jasiüniene $v \quad$ Lithuania App no 41510/98 (ECtHR, $6 \quad$ March 2003).

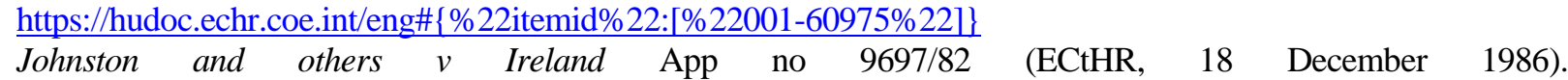
https://hudoc.echr.coe.int/eng\#\{\%22itemid\%22:[\%22001-57508\%22]\}

15. Jonasson $v$ Sweden App no 59403/00 (ECtHR, 12 July 2005).

16. $K$. and T. $\quad v$ Finland App no 25702/94 $\quad$ (ECtHR, 12 July 2001$)$. https://hudoc.echr.coe.int/eng\#\{\%22itemid\%22:[\%22001-59587\%22]\}

17. Kalanyos and Others $v$ Romania App no 57884/00 (ECtHR, 26 April 2007).

18. Kearns v France App no 35991/04 (ECtHR, 10 January 2008). https://swarb.co.uk/kearns-v-france-echr-10-jan$\underline{2008 /}$

19. Keegan v Ireland App no 16969/90 (ECtHR, 26 May 1994). https://hudoc.echr.coe.int/eng?i=001-57881

20. L. $v$ the Netherlands App no $45582 / 99 \quad$ (ECtHR, 1 June 2004$)$. https://www.refworld.org/cases,ECHR,5852a7e54.html

21. Lück v Germany App no 58364/00 (ECtHR, 15 May 2008).

22. Macready $v$ the Czech Republic App no 4824/06 and 15512/08 (ECtHR, 22 April 2010). https://www.incadat.com/en/case/1159

23. Maurice v France [GC] App no 11810/03 (ECtHR, 6 October 2005). https://hudoc.echr.coe.int/eng?i=001-70445

24. Mitovi v the former Yugoslav Republic of Macedonia (so-called Republic of North Macedonia since February 2019), App no 53565/13 (ECtHR, 16 April 2015).

25. Perez Arias v Spain App no 32978/03 (ECtHR, 28 June 2007). http://echr.ketse.com/doc/32978.03-en-20070628/

26. Przydziat $v$ Poland App no $15487 / 08 \quad$ (ECtHR, $24 \quad$ May 2016). https://hudoc.echr.coe.int/app/conversion/pdf?library=ECHR\&id=003-53828866727820\&filename=Judgments\%20of\%2024.05.16.pdf

27. R. v the UK App no 10496/83 (for the remainder of the admissibility decision R. v the UK, European Commission of Human Rights (hereafter 'ECmHR'), 14 May 1984) (ECtHR, 8 July 1987).

28. Rodrigues Da Silva and Hoogkamer $v$ the Netherlands App no 50435/99 (ECtHR, 31 January 2006). https://hudoc.echr.coe.int/eng?i=001-72205

29. Ruianu v Romania App no 34647/97 (ECtHR, 17 June 2003). https://ru.scribd.com/document/332821744/ECHRGuide-Art-6-Civil-ENG

30. Rytchenko $\quad v \quad$ Russia App no 22266/04 $\quad$ (ECtHR, $20 \quad$ January 2011). http://hudoc.echr.coe.int/app/conversion/pdf/?library=ECHR\&id=001-102894\&filename=001-102894.pdf

31. Salduz v Turkey App no 36391/02 (ECtHR, 27 November 2008). https://hudoc.echr.coe.int/eng?i=001-89893

32. Santos Nunes $v$ Portugal App no 61173/08 $\quad$ (ECtHR, $22 \quad$ May 2012 ). https://vaikoteises.lt/media/file/ivaikinimas2/ECHR_cases_concerning_children_r.doc.pdf

33. Satakunnan Markkinapörssi Oy and Satamedia Oy v Finland [GC] App no 931/13 (ECtHR, 27 June 2017). https://hudoc.echr.coe.int/eng\#\{\%22itemid\%22:[\%22001-175121\%22]\}

34. Schwarzkopf and Taussik $v$ the Czech Republic (dec.) App no 42162/02 (ECtHR, 2 December 2008). 
35. Senchishak v. Finland App no 5049/12 (ECtHR, 18 November 2014). https://hudoc.echr.coe.int/eng\#\{\%22itemid\%22:[\%22001-148076\%22]\}

36. Soares de Melo v Portugal App no 72850/14 (ECtHR, 16 February 2016). https://opil.ouplaw.com/view/10.1093/law-ihrl/4018echr16.case.1/law-ihrl-4018echr16

37. Ştefan and Ştef $v$ Romania App nos. 24428/03 and 26977/03 (ECtHR, 27 January 2009).

38. Tapia Gasca and D. $v$ Spain App no 20272/06 (ECtHR, 22 December 2009). https://crossbordermediator.eu/Portals/1/Docs/Hear me out Case Law Results.pdf

39. Vereshchagin and Others $v$ Russia App no 30155/05 et al. (ECtHR, 14 June 2018). https://hudoc.echr.coe.int/eng\#\{\%22itemid\%22:[\%22001-101936\%22]\}

\section{Appendix}

Table 1. Comparative research table of the ECtHR case law involving articles 6 and 8 ECHR (1998-2018)

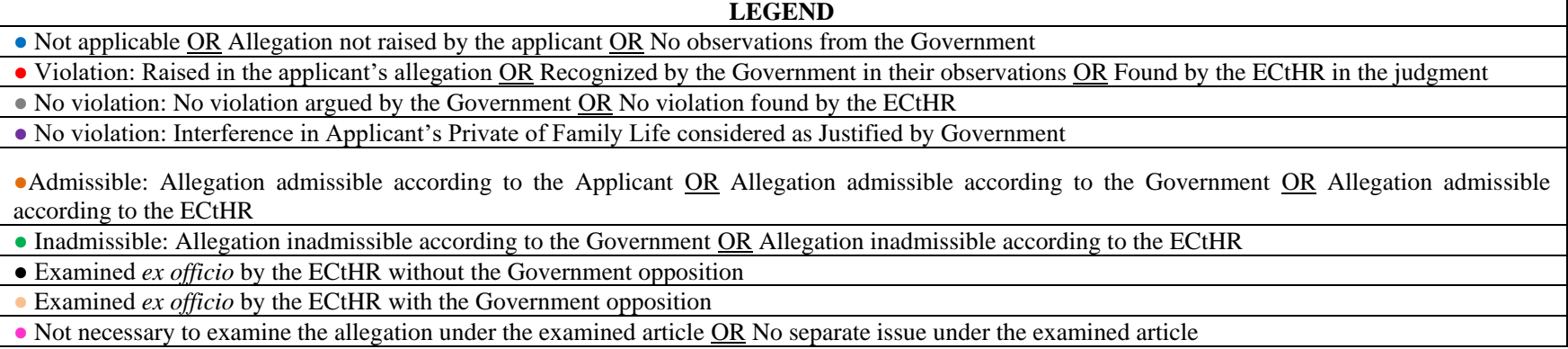

\begin{tabular}{|c|c|c|c|c|c|c|c|c|c|c|c|}
\hline $\begin{array}{l}\text { 岁 } \\
\approx \\
\approx\end{array}$ & No. & Case Title & Case No. & $\begin{array}{l}\text { Date of } \\
\text { Judgment }\end{array}$ & $\begin{array}{l}\text { Issue at stake } \\
\text { Annual Report/Legal } \\
\text { Summary/Press Release }\end{array}$ & 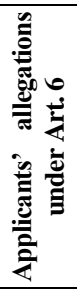 & 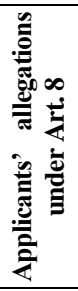 & 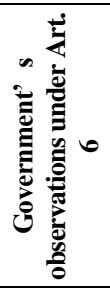 & 事 & ט. & م \\
\hline \multirow{5}{*}{ 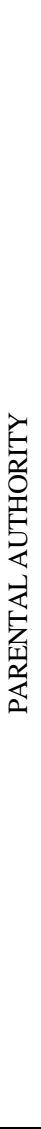 } & 2. & $\begin{array}{l}\text { Assunção } \\
\text { Chaves } \quad v \\
\text { Portugal }\end{array}$ & $61226 / 08$ & $31 / 01 / 12$ & $\begin{array}{l}\text { Failure to duly inform the } \\
\text { applicant, who was neither } \\
\text { present nor represented at the } \\
\text { hearing, of the procedure for } \\
\text { challenging a court order } \\
\text { withdrawing his parental } \\
\text { authority. }\end{array}$ & $\bullet$ & $\bullet$ & $\bullet$ & $\bullet$ & - & $\bullet$ \\
\hline & 3. & $\begin{array}{l}\text { Iordache } \quad v \\
\text { Romania }\end{array}$ & $6817 / 02$ & $14 / 10 / 08$ & $\begin{array}{l}\text { Automatic application of a } \\
\text { ban on the exercising of } \\
\text { parental authority. }\end{array}$ & $\bullet$ & $\bullet$ & $\bullet$ & $\bullet$ & $\bullet$ & $\bullet$ \\
\hline & 4. & $\begin{array}{l}\text { Calmanovici } v \\
\text { Romania }\end{array}$ & $42250 / 02$ & 01/07/08 & $\begin{array}{l}\text { The lawfulness of the initial } \\
\text { and continued placement in } \\
\text { pre-trial detention, and the } \\
\text { fairness of the criminal } \\
\text { proceedings; the surveillance } \\
\text { measures applied; the } \\
\text { deprivation of parental } \\
\text { authority for the period of } \\
\text { imprisonment. }\end{array}$ & $\bullet$ & $\bullet$ & $\bullet$ & $\bullet$ & $\bullet$ & $\bullet$ \\
\hline & 5. & $\begin{array}{l}\text { Hunt } \quad v \\
\text { Ukraine }\end{array}$ & $31111 / 04$ & $07 / 12 / 06$ & $\begin{array}{l}\text { Ban from entering the country } \\
\text { in which proceedings for the } \\
\text { deprivation of parental rights } \\
\text { were engaged against the } \\
\text { applicant (understood as } \\
\text { parental authority) and ended } \\
\text { without him been heard. }\end{array}$ & $\bullet$ & $\bullet$ & $\bullet$ & - & $\bullet$ & $\bullet$ \\
\hline & 6. & $\begin{array}{l}\text { Reslová } v \text { the } \\
\text { Czech } \\
\text { Republic }\end{array}$ & $7550 / 04$ & $18 / 07 / 06$ & $\begin{array}{l}\text { The exercise of parental } \\
\text { authority and the failure to } \\
\text { respect the right of access to a } \\
\text { child. }\end{array}$ & $\bullet$ & $\bullet$ & $\bullet$ & $\bullet$ & $\bullet$ & $\bullet$ \\
\hline
\end{tabular}


Table 1 (cont.). Comparative research table of the ECtHR case law involving articles 6 and 8 ECHR (1998-2018)

\begin{tabular}{|c|c|c|c|c|c|c|c|c|c|c|c|}
\hline $\begin{array}{l}\int^{2} \\
\vdots \\
n \\
n\end{array}$ & No. & Case Title & Case No. & $\begin{array}{c}\text { Date of } \\
\text { Judgment }\end{array}$ & $\begin{array}{c}\text { Issue at stake } \\
\text { Annual Report/Legal } \\
\text { Summary/Press Release }\end{array}$ & 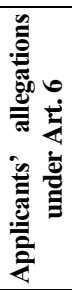 & 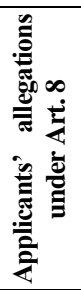 & 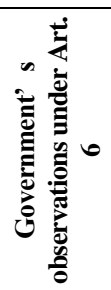 & 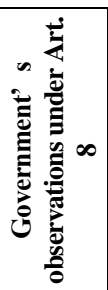 & 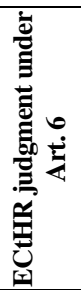 & 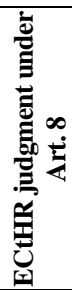 \\
\hline & 7. & $\begin{array}{l}\text { Maršálek v the } \\
\text { Czech } \\
\text { Republic }\end{array}$ & $8153 / 04$ & $04 / 04 / 06$ & $\begin{array}{l}\text { The excessive length of } \\
\text { parental } \\
\text { proceedings. }\end{array}$ & $\bullet$ & $\bullet$ & $\bullet$ & $\cdot$ & $\bullet$ & $\cdot$ \\
\hline & 8. & $\begin{array}{l}\text { Cambal } v \text { the } \\
\text { Czech } \\
\text { Republic }\end{array}$ & $22771 / 04$ & $21 / 02 / 06$ & $\begin{array}{l}\text { The parental authority } \\
\text { proceedings and visit rights } \\
\text { of the father. }\end{array}$ & - & - & $\bullet$ & - & - & - \\
\hline & 9. & $\begin{array}{l}\text { Venema } v \text { the } \\
\text { Netherlands }\end{array}$ & $35731 / 97$ & $17 / 12 / 02$ & $\begin{array}{l}\text { Withdrawal of parental rights } \\
\text { (understood as parental } \\
\text { authority). }\end{array}$ & - & - & - & - & - & - \\
\hline & 10. & $\begin{array}{ll}\text { Hoppe } & v \\
\text { Germany }\end{array}$ & $28422 / 95$ & $05 / 12 / 02$ & $\begin{array}{l}\text { The case for parental } \\
\text { authority over a child, } \\
\text { engaged by the child's } \\
\text { parents. }\end{array}$ & $\bullet$ & - & $\bullet$ & $\bullet$ & $\bullet$ & $\bullet$ \\
\hline
\end{tabular}

Table 1a. Comparative research table of the ECtHR case law involving articles 6 and 8 ECHR (1998-2018)

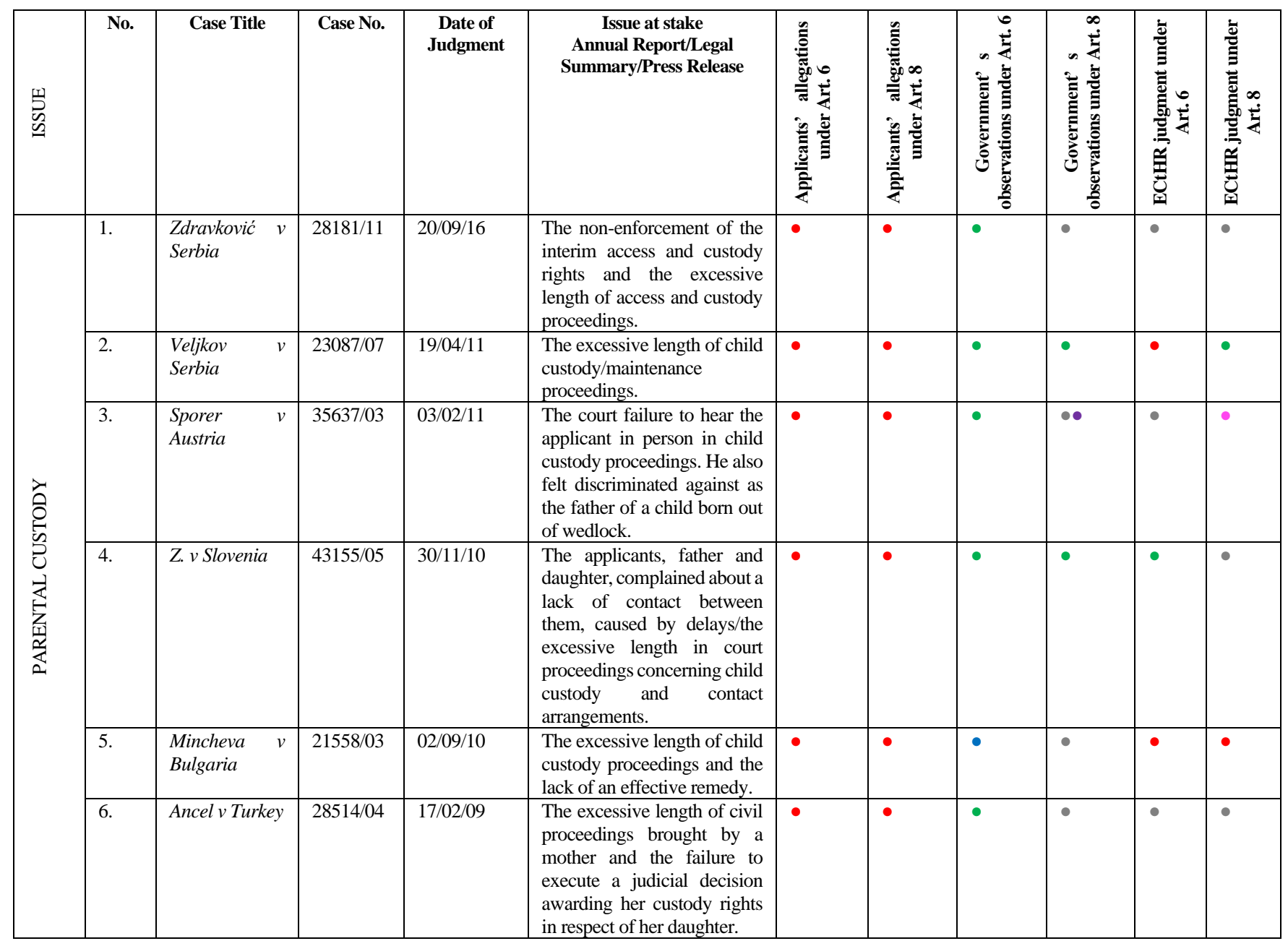


Table 1a (cont.). Comparative research table of the ECtHR case law involving articles 6 and 8 ECHR (19982018)

\begin{tabular}{|c|c|c|c|c|c|c|c|c|c|c|}
\hline 7. & K.T.v Norway & $26664 / 03$ & $25 / 09 / 08$ & $\begin{array}{l}\text { Breach of the right to family } \\
\text { life by a second investigation } \\
\text { of child welfare services into } \\
\text { the applicant's parental } \\
\text { abilities, and affecting the } \\
\text { applicant's right to custody, } \\
\text { after an initial investigation } \\
\text { had concluded that the } \\
\text { children did not need to be } \\
\text { taken into care. The summary } \\
\text { dismissal of the applicant's } \\
\text { action challenging the second } \\
\text { investigation, which violated } \\
\text { his right of access to a court. }\end{array}$ & $\bullet$ & $\bullet$ & $\bullet$ & $\bullet$ & $\bullet$ & $\bullet$ \\
\hline 8. & $\begin{array}{l}\text { Bevacqua and } \\
\text { S. v Bulgaria }\end{array}$ & $71127 / 01$ & $12 / 06 / 08$ & $\begin{array}{l}\text { The authorities' failure to } \\
\text { ensure respect for their } \\
\text { private and family life in a } \\
\text { difficult situation caused by } \\
\text { their divorce and the former } \\
\text { husband's behaviour and the } \\
\text { excessive length of custody } \\
\text { proceedings. }\end{array}$ & $\bullet$ & $\bullet$ & $\bullet$ & $\bullet$ & $\bullet$ & $\bullet$ \\
\hline 9. & $\begin{array}{l}\text { Schmidt } \quad v \\
\text { France }\end{array}$ & $35109 / 02$ & $26 / 07 / 07$ & $\begin{array}{l}\text { An infringement of the right } \\
\text { to respect for family life on } \\
\text { account of the deprivation of } \\
\text { child custody and their } \\
\text { daughter's placement into } \\
\text { care. The lack of access to a } \\
\text { court and the excessive } \\
\text { length of proceedings. }\end{array}$ & $\bullet$ & $\bullet$ & $\bullet$ & $\bullet$ & $\bullet$ & $\bullet$ \\
\hline 10. & $\begin{array}{l}\text { Wallová and } \\
\text { Walla v the } \\
\text { Czech } \\
\text { Republic }\end{array}$ & $23848 / 04$ & $26 / 10 / 06$ & $\begin{array}{l}\text { Deprivation of child custody } \\
\text { by taking the children into } \\
\text { care, away from the parents on } \\
\text { the sole ground that the } \\
\text { family's housing was } \\
\text { inadequate. The excessive } \\
\text { length of proceedings. }\end{array}$ & $\bullet$ & $\bullet$ & $\bullet$ & $\bullet$ & $\bullet$ & $\bullet$ \\
\hline 11. & H.K. v Finland & $36065 / 97$ & $26 / 09 / 06$ & $\begin{array}{l}\text { The applicant's four-year-old } \\
\text { daughter was removed from } \\
\text { him on suspicion that she had } \\
\text { been sexually abused, and } \\
\text { placed in her mother's } \\
\text { custody. The applicant } \\
\text { objected to the child's } \\
\text { placement with the mother, } \\
\text { because of the absence of a } \\
\text { formal decision to that effect } \\
\text { and a restriction on applicant's } \\
\text { custody, access and his lack of } \\
\text { involvement in the decision- } \\
\text { making process. }\end{array}$ & $\bullet$ & $\bullet$ & $\bullet$ & $\bullet$ & $\bullet$ & $\bullet$ \\
\hline 12. & $\begin{array}{ll}\text { Moser } & v \\
\text { Austria } & \end{array}$ & $12643 / 02$ & $21 / 09 / 06$ & $\begin{array}{l}\text { The mother raised a breach of } \\
\text { her and her child's right to } \\
\text { family life, because the child } \\
\text { custody was transferred to the } \\
\text { Youth Welfare Office. She } \\
\text { also raised: the lack of } \\
\text { opportunity to comment on } \\
\text { the reports of the Youth } \\
\text { Welfare Office and the } \\
\text { Juvenile Court Assistance } \\
\text { Office; the Court's failure to } \\
\text { hold a public hearing and to } \\
\text { pronounce the judgments in } \\
\text { those proceedings publicly. }\end{array}$ & $\bullet$ & $\bullet$ & $\bullet$ & $\bullet$ & $\bullet$ & $\bullet$ \\
\hline 13. & $\begin{array}{l}\text { Dostál v the } \\
\text { Czech } \\
\text { Republic }\end{array}$ & $26739 / 04$ & $21 / 02 / 06$ & $\begin{array}{l}\text { The excessive length of } \\
\text { proceedings on custody and } \\
\text { visit rights of the child's father. }\end{array}$ & $\bullet$ & $\bullet$ & $\bullet$ & $\bullet$ & $\bullet$ & $\bullet$ \\
\hline 14. & $\begin{array}{l}\text { Mihailova } v \\
\text { Bulgaria }\end{array}$ & $35978 / 02$ & $12 / 01 / 06$ & $\begin{array}{l}\text { Non-enforcement of a custody } \\
\text { order by the authorities and } \\
\text { the excessive length of these } \\
\text { proceedings. }\end{array}$ & $\bullet$ & $\bullet$ & $\bullet$ & $\bullet$ & $\bullet$ & $\bullet$ \\
\hline
\end{tabular}


Table 1a (cont.). Comparative research table of the ECtHR case law involving articles 6 and 8 ECHR (1998-2018

\begin{tabular}{|c|c|c|c|c|c|c|c|c|c|c|c|}
\hline$\dot{\mathbf{z}}$ & 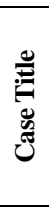 & 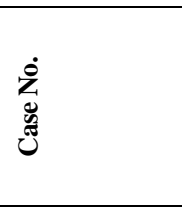 & 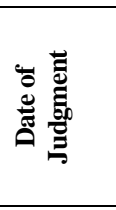 & 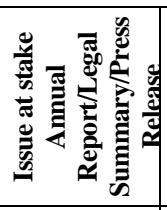 & 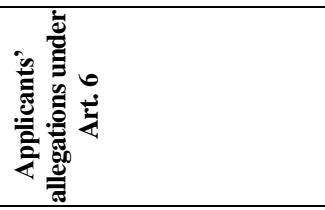 & 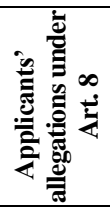 & 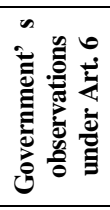 & 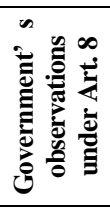 & 曾苛 & 关兽 & $\dot{\mathbf{z}}$ \\
\hline & 15. & $\begin{array}{l}\text { Buchberger v } \\
\text { Austria }\end{array}$ & $32899 / 96$ & $20 / 12 / 01$ & $\begin{array}{l}\text { Deprivation of custody over a } \\
\text { child and the mother's } \\
\text { capacity to care for her } \\
\text { children in view, among other } \\
\text { things, of her failure to protect } \\
\text { another of her children against } \\
\text { physical abuse by her former } \\
\text { partner. She raised the issue } \\
\text { that the Court relied on fresh } \\
\text { evidence about which she was } \\
\text { not informed and she had no } \\
\text { possibility to react to it }\end{array}$ & $\bullet$ & $\bullet$ & $\bullet$ & $\bullet$ & $\bullet$ & $\bullet$ \\
\hline & 17. & E.P. v Italy & $31127 / 96$ & $16 / 11 / 99$ & $\begin{array}{l}\text { Placing into care/suspension } \\
\text { of the right to custody and } \\
\text { contact with a child on the } \\
\text { basis of a psychiatric report } \\
\text { stating that the child was } \\
\text { suffering from emotional and } \\
\text { relational disorders caused by } \\
\text { her mother's pathological } \\
\text { behaviour. The child has } \\
\text { finally been adopted by foster } \\
\text { parents. The excessive length } \\
\text { of the custody proceedings } \\
\text { (seven years). }\end{array}$ & $\bullet$ & $\bullet$ & $\bullet$ & $\bullet$ & $\bullet$ & $\bullet$ \\
\hline & 18. & Buscemi v Italy & $29569 / 95$ & $16 / 09 / 99$ & $\begin{array}{l}\text { A court refusing several } \\
\text { times to grant custody of a } \\
\text { child to her father (Article } 8 \text { ). } \\
\text { The presiding judge in the } \\
\text { child custody proceedings } \\
\text { having been publicly } \\
\text { engaged in a controversy } \\
\text { with the father, because he } \\
\text { publicly used expressions } \\
\text { which implied that he had } \\
\text { already formed an } \\
\text { unfavourable view in the } \\
\text { applicant's case. } \\
\text { Incompatibility with the } \\
\text { principle of impartiality of a } \\
\text { court. }\end{array}$ & $\bullet$ & $\bullet$ & $\bullet$ & $\bullet$ & $\bullet$ & $\bullet$ \\
\hline
\end{tabular}


Table 1b. Comparative research table of the ECtHR case law involving articles 6 and 8 ECHR (1998-2018)

\begin{tabular}{|c|c|c|c|c|c|c|c|c|c|c|c|}
\hline $\begin{array}{l}\text { 山े } \\
\tilde{\Omega} \\
气\end{array}$ & No. & Case Title & Case No. & $\begin{array}{l}\text { Date of } \\
\text { Judgment }\end{array}$ & $\begin{array}{l}\text { Issue at stake } \\
\text { Annual Report/Legal } \\
\text { Summary/Press Release }\end{array}$ & 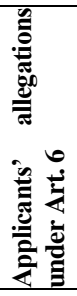 & 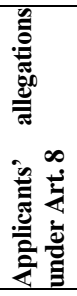 & 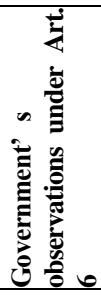 & 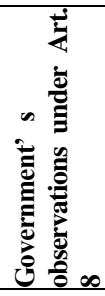 & ס & 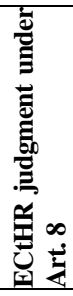 \\
\hline 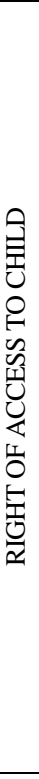 & 2. & Ribićv Croatia & $27148 / 12$ & $02 / 04 / 15$ & $\begin{array}{l}\text { The excessive length of } \\
\text { proceedings for contact } \\
\text { rights with the applicant's } \\
\text { son. }\end{array}$ & $\bullet$ & $\bullet$ & $\bullet$ & $\bullet$ & $\bullet$ & $\bullet$ \\
\hline & 4. & $\begin{array}{l}\text { Cengiz Kiliç v } \\
\text { Turkey }\end{array}$ & $16192 / 06$ & $06 / 12 / 11$ & $\begin{array}{l}\text { Inability of a father to } \\
\text { exercise his contact rights } \\
\text { (non-enforcement) in } \\
\text { relation to his son during } \\
\text { the course of divorce } \\
\text { proceedings. The lack of } \\
\text { an effective remedy to } \\
\text { complain about the } \\
\text { excessive length of } \\
\text { proceedings. }\end{array}$ & $\bullet$ & $\bullet$ & $\bullet$ & - & $\bullet$ & $\bullet$ \\
\hline & 5. & $\begin{array}{l}\text { Tsikakis } \quad v \\
\text { Germany }\end{array}$ & $1521 / 06$ & $10 / 02 / 11$ & $\begin{array}{l}\text { Deprivation of access } \\
\text { rights. The excessive } \\
\text { length of } \\
\text { proceedings. }\end{array}$ & $\bullet$ & $\bullet$ & $\bullet$ & $\bullet$ & $\bullet$ & $\bullet$ \\
\hline & 6. & $\begin{array}{l}\text { Rytchenko v } \\
\text { Russia }\end{array}$ & $22266 / 04$ & $20 / 01 / 11$ & $\begin{array}{l}\text { Deprivation of access } \\
\text { rights. The excessive } \\
\text { length of } \\
\text { proceedings. }\end{array}$ & $\bullet$ & $\bullet$ & $\bullet$ & $\bullet$ & $\bullet$ & - \\
\hline & 7. & Övüş v Turkey & $42981 / 04$ & $13 / 10 / 09$ & $\begin{array}{l}\text { Non-enforcement of } \\
\text { access rights. The } \\
\text { excessive length of access } \\
\text { and divorce proceedings. }\end{array}$ & $\bullet$ & $\bullet$ & $\bullet$ & $\bullet$ & $\bullet$ & $\bullet$ \\
\hline & 8. & $\begin{array}{l}\text { Zavrel } v \text { the } \\
\text { Czech } \\
\text { Republic }\end{array}$ & $14044 / 05$ & $18 / 01 / 07$ & $\begin{array}{l}\text { Non-enforcement of } \\
\text { access right to a child. Fair } \\
\text { trial and the excessive } \\
\text { length of proceedings. }\end{array}$ & $\bullet$ & $\bullet$ & $\bullet$ & $\bullet$ & $\bullet$ & $\bullet$ \\
\hline & 9. & $\begin{array}{l}\text { Křrz v the } \\
\text { Czech } \\
\text { Republic }\end{array}$ & $26634 / 03$ & $09 / 01 / 07$ & $\begin{array}{l}\text { Non-enforcement of } \\
\text { access right to a child. The } \\
\text { excessive length of } \\
\text { proceedings. }\end{array}$ & $\bullet$ & $\bullet$ & $\bullet$ & $\bullet$ & $\bullet$ & $\bullet$ \\
\hline & 10. & $\begin{array}{l}\text { Roda and } \\
\text { Bonfatti v Italy }\end{array}$ & $10427 / 02$ & $21 / 11 / 06$ & $\begin{array}{l}\text { Access to the file and an } \\
\text { effective remedy to } \\
\text { complain about it. The } \\
\text { right of access/contact of } \\
\text { parents and a child placed } \\
\text { in care. }\end{array}$ & $\bullet$ & $\bullet$ & $\bullet$ & $\bullet$ & $\bullet$ & $\bullet$ \\
\hline
\end{tabular}


Tableb (cont.). Comparative research table of the ECtHR case law involving articles 6 and 8 ECHR (1998-2018।

\begin{tabular}{|c|c|c|c|c|c|c|c|c|c|c|c|}
\hline 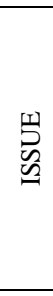 & No. & Case Title & Case No. & $\begin{array}{l}\text { Date of } \\
\text { Judgment }\end{array}$ & $\begin{array}{l}\text { Issue at stake } \\
\text { Annual Report/Legal } \\
\text { Summary/Press Release }\end{array}$ & 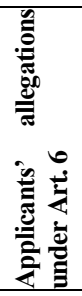 & 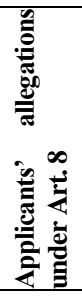 & 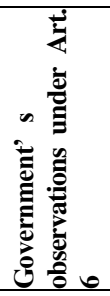 & 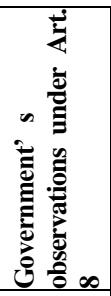 & 葛 & 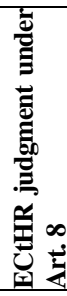 \\
\hline & 12. & $\begin{array}{l}\text { Lubina } \quad v \\
\text { Slovakia }\end{array}$ & $77688 / 01$ & $19 / 09 / 06$ & $\begin{array}{l}\text { The excessive length of } \\
\text { access proceedings. } \\
\text { Impossibility to meet the } \\
\text { child due to the national } \\
\text { courts' failure to decide on } \\
\text { the case speedily. }\end{array}$ & $\bullet$ & $\bullet$ & - & $\bullet$ & $\bullet$ & $\bullet$ \\
\hline & 13. & $\begin{array}{l}\text { Koudelka v the } \\
\text { Czech } \\
\text { Republic }\end{array}$ & $1633 / 05$ & $20 / 07 / 06$ & $\begin{array}{l}\text { Non-enforcement of } \\
\text { access rights. The } \\
\text { excessive length of access. }\end{array}$ & $\bullet$ & $\bullet$ & $\bullet$ & $\bullet$ & $\bullet$ & $\bullet$ \\
\hline & 14. & $\begin{array}{l}\text { Fiala v the } \\
\text { Czech } \\
\text { Republic }\end{array}$ & $26141 / 03$ & $18 / 07 / 06$ & 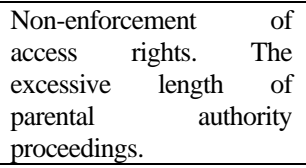 & $\bullet$ & $\bullet$ & $\bullet$ & $\bullet$ & $\bullet$ & $\bullet$ \\
\hline & 15 . & $\begin{array}{l}\text { Pedovič v the } \\
\text { Czech } \\
\text { Republic }\end{array}$ & $27145 / 03$ & $18 / 07 / 06$ & $\begin{array}{l}\text { The excessive length of } \\
\text { maintenance proceedings. } \\
\text { The excessive length and } \\
\text { non-enforcement of access } \\
\text { rights. }\end{array}$ & $\bullet$ & $\bullet$ & $\bullet$ & $\bullet$ & $\bullet$ & $\bullet$ \\
\hline & 16. & $\begin{array}{l}\text { Rylski } \quad v \\
\text { Poland }\end{array}$ & $24706 / 02$ & $04 / 07 / 06$ & $\begin{array}{l}\text { Non-enforcement of } \\
\text { access rights. Access to a } \\
\text { court in divorce } \\
\text { proceedings. The } \\
\text { excessive length of divorce } \\
\text { proceedings. }\end{array}$ & $\bullet$ & $\bullet$ & $\bullet$ & $\bullet$ & $\bullet$ & $\bullet$ \\
\hline & 17. & $R . v$ Finland & $34141 / 96$ & $30 / 05 / 06$ & $\begin{array}{l}\text { Deprivation of access } \\
\text { rights because no adequate } \\
\text { measures were taken to } \\
\text { reunify the family by the } \\
\text { public care institution. } \\
\text { Participation in a trial. The } \\
\text { excessive length of access } \\
\text { proceedings. }\end{array}$ & $\bullet$ & $\bullet$ & $\bullet$ & $\bullet$ & $\bullet \bullet$ & $\bullet$ \\
\hline & 18. & $\begin{array}{l}\text { Plasse-Bauer } v \\
\text { France }\end{array}$ & $21324 / 02$ & $28 / 02 / 06$ & $\begin{array}{l}\text { Non-enforcement } \quad \text { of } \\
\text { access rights. }\end{array}$ & $\bullet$ & $\bullet$ & $\bullet$ & $\bullet$ & $\bullet$ & $\bullet$ \\
\hline & 19. & $\begin{array}{l}\text { Sommerfeld } v \\
\text { Germany }[\mathrm{GC}]\end{array}$ & $31871 / 96$ & $08 / 07 / 03$ & $\begin{array}{l}\text { Refusal to grant the father } \\
\text { access rights to a child born } \\
\text { out of wedlock. Different } \\
\text { treatment of natural fathers } \\
\text { and divorced fathers with } \\
\text { regard to access rights. } \\
\text { Discriminatory treatment } \\
\text { in access rights. }\end{array}$ & $\bullet$ & $\bullet$ & $\bullet$ & $\bullet$ & $\bullet$ & $\bullet$ \\
\hline & 20. & $\begin{array}{l}P ., C . \text { and } S . v \\
\text { the } U K\end{array}$ & $56547 / 00$ & $16 / 07 / 02$ & $\begin{array}{l}\text { Restrictions on access } \\
\text { rights to a child in care. } \\
\text { The lack of legal } \\
\text { representation } \\
\text { proceedings concerning } \\
\text { childcare and access rights. } \\
\text { The lack of legal } \\
\text { representation } \\
\text { proceedings concerning } \\
\text { childcare and access rights. }\end{array}$ & $\bullet$ & $\bullet$ & $\bullet$ & $\bullet$ & $\bullet$ & $\bullet$ \\
\hline
\end{tabular}


Table 1b (cont.). Comparative research table of the ECtHR case law involving articles 6 and 8 ECHR (1998-2018।

\begin{tabular}{|c|c|c|c|c|c|c|c|c|c|c|c|}
\hline 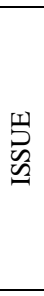 & No. & Case Title & Case No. & $\begin{array}{l}\text { Date of } \\
\text { Judgment }\end{array}$ & $\begin{array}{l}\text { Issue at stake } \\
\text { Annual Report/Legal } \\
\text { Summary/Press Release }\end{array}$ & 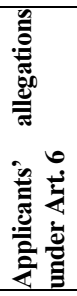 & 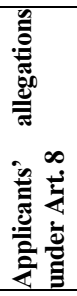 & 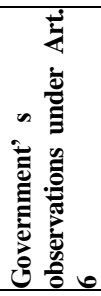 & 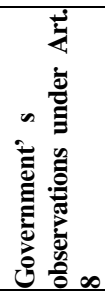 & 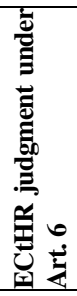 & 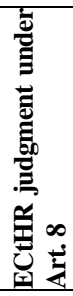 \\
\hline & 22. & $\begin{array}{l}\text { Gnahoré } \quad v \\
\text { France }\end{array}$ & $40031 / 98$ & $19 / 09 / 00$ & $\begin{array}{l}\text { Refusal of a request for } \\
\text { legal aid due to the absence } \\
\text { of serious grounds of } \\
\text { appeal. Restrictions on } \\
\text { access rights to a child in } \\
\text { care. }\end{array}$ & $\bullet$ & $\bullet$ & $\bullet$ & $\bullet$ & $\bullet$ & $\bullet$ \\
\hline & 23. & $\begin{array}{l}\text { Glaser } v \text { the } \\
\text { UK }\end{array}$ & $32346 / 96$ & $19 / 09 / 00$ & \begin{tabular}{lr}
\multicolumn{2}{l}{ Non-enforcement } \\
access rights. The \\
excessive length of \\
enforcement proceedings.
\end{tabular} & $\bullet$ & $\bullet$ & $\bullet$ & $\bullet$ & $\bullet$ & $\bullet$ \\
\hline & 24. & $\begin{array}{l}\text { Scozzari and } \\
\text { Giunta v Italy } \\
{[\mathrm{GC}]}\end{array}$ & $\begin{array}{l}39221 / 98 \text { et } \\
\text { al. }\end{array}$ & $13 / 07 / 00$ & $\begin{array}{l}\text { Taking of children into } \\
\text { care and suspension of } \\
\text { parental rights; Restriction } \\
\text { of mother's right of access } \\
\text { to children in care; The } \\
\text { placement of children into } \\
\text { a community where certain } \\
\text { personnel had convictions } \\
\text { for paedophilia. The } \\
\text { excessive length of the } \\
\text { examination of the } \\
\text { applicants' appeals before } \\
\text { the domestic courts. }\end{array}$ & $\bullet / \bullet$ & $\bullet$ & - & $\bullet$ & $\bullet$ & $\bullet \bullet$ \\
\hline & 25. & $\begin{array}{lr}\text { Elsholz } v \\
\text { Germany [GC] }\end{array}$ & $25735 / 94$ & $13 / 07 / 00$ & $\begin{array}{l}\text { Refusal to grant the father } \\
\text { access rights to a child born } \\
\text { out of wedlock - } \\
\text { insufficient involvement in } \\
\text { the decision-making } \\
\text { process. Failure to obtain } \\
\text { an expert opinion in } \\
\text { respect of child access and } \\
\text { failure to hold a hearing on } \\
\text { appeal. Different treatment } \\
\text { of natural fathers and } \\
\text { divorced fathers with } \\
\text { regard to access rights. }\end{array}$ & $\bullet$ & $\bullet$ & $\bullet$ & $\bullet$ & $\bullet$ & $\bullet$ \\
\hline & 26. & $\begin{array}{l}\text { Nuutinen } v \\
\text { Finland }\end{array}$ & $32842 / 96$ & $27 / 06 / 00$ & $\begin{array}{l}\text { Non-enforcement } \\
\text { access rights. The } \\
\text { excessive length of } \\
\text { proceedings including } \\
\text { access rights. }\end{array}$ & $\bullet$ & $\bullet$ & - & $\bullet$ & $\bullet$ & 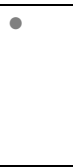 \\
\hline & 27. & L. v Finland & $25651 / 94$ & $27 / 04 / 00$ & $\begin{array}{l}\text { Restrictions on access } \\
\text { rights to child in care. The } \\
\text { lack of an oral hearing. }\end{array}$ & $\bullet$ & $\bullet$ & $\bullet$ & $\bullet$ & $\bullet$ & $\bullet$ \\
\hline
\end{tabular}

